OAK RIDGE NATIONAL LABORATORY

LOCKHEED MA RTIN

\section{Technical Report for Generic Site Add-On Facility for Plutonium Polishing}

June 1998

Compiled by

Multisite Team from

Oak Ridge National Laboratory

Savannah River Site

LOCKHEED MARTIN ENERGY RESEARCH CORPORATION FOR THE UNITED STATES

Los Alamos National Laboratory 
This report has been reproduced directly from the best available copy.

Available to DOE and DOE contractors from the Office of Scientific and Technical Information, P. O. Box 62, Oak Ridge, TN 37831; prices available from (423) 576-8401.

Available to the public from the National Technical Information Service, U.S. Department of Commerce, 5285 Port Royal Rd., Springfield, VA 22161.

This report was prepared as an account of work sponsored by an agency of the United State Government. Neither the United States Government nor any agency thereof, nor any of their employees, makes any warranty, express or implied, or assumes any legal liability or responsibility for the accuracy, completeness, or usefulness of any information, apparatus, product, or process disclosed, or represents that its use would not infringe privately owned rights. Reference herein to any specific commercial product, process, or service by trade name, trademark, manufacturer, or otherwise, does not necessarily constitute or imply its endorsement, recommendation, or favoring by the United States Government or any agency thereof. 
Technical Report for Generic Site Add-On Facility for Plutonium Polishing

Fissile Materials Disposition Program

\author{
Compiled By \\ Multisite Team from \\ Oak Ridge National Laboratory \\ Savannah River Site \\ Los Alamos National Laboratory
}

June 1998

\author{
Prepared by the \\ OAK RIDGE NATIONAL LABORATORY \\ Oak Ridge, Tennessee 37831 \\ managed by \\ LOCKHEED MARTIN ENERGY RESEARCH CORP. \\ for the \\ U.S. DEPARTMENT OF ENERGY \\ under contract DE-AC05-96OR22464
}


Revision History

\begin{tabular}{|c|c|c|}
\hline Revision number & Date issued & Reason for revision \\
\hline 0 & June 1998 & \\
\hline
\end{tabular}


Multisite Team

E. D. Collins, ORNL, Chair

ORNL

D. O. Campbell

R. T. Jubin

R. E. Norman

W. D. Bond
LANL

S. F. DeMuth

S. L. Yarbro

P. Chodak

J. F. Heneage
SRS

J. M. McKibben

M. C. Thompson

R. L. Geddes

T. F. Severynse

S. W. Rogers

R. S. Matthews

L. D. Milton 


\section{CONTENTS}

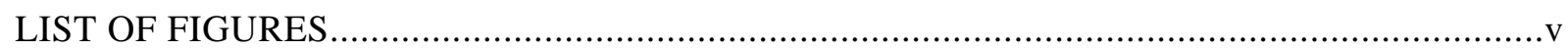

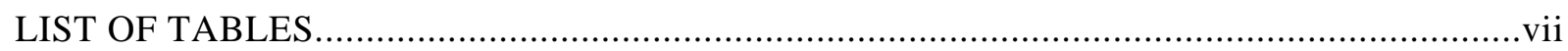

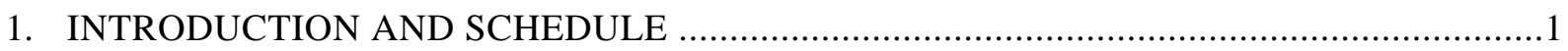

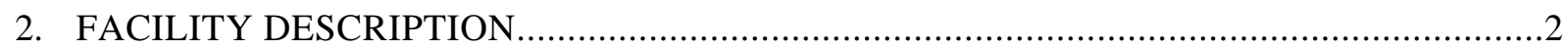

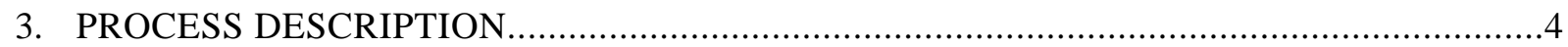

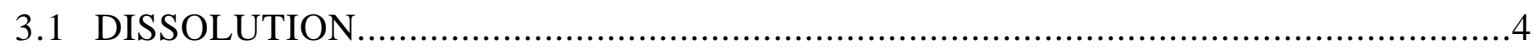

3.2 IMPURITY REMOVAL ................................................................................... 7

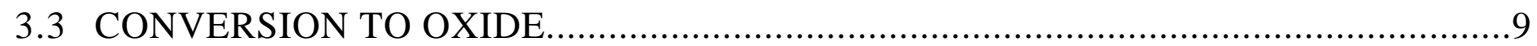

3.4 LIQUID WASTE HANDLING AND ACID RECOVERY ….......................................

3.5 SOLID WASTE TREATMENT ......................................................................... 13

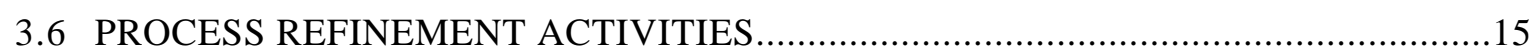

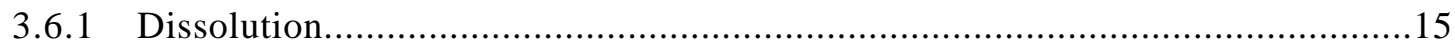

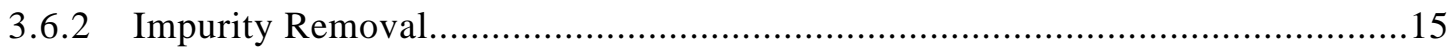

3.6.3 Plutonium Valence Adjustment.............................................................. 15

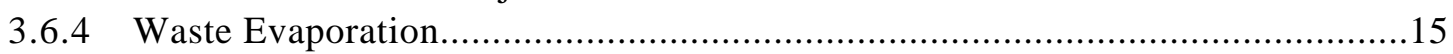

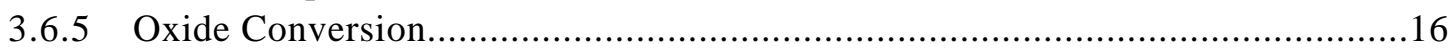

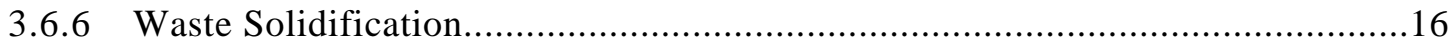

3.6.7 Process Control and Automation.............................................................. 16

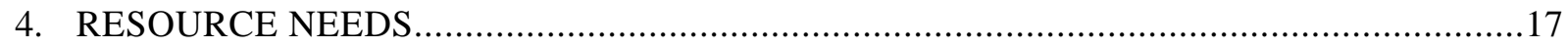

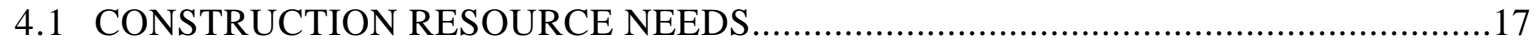

4.2 OPERATIONS RESOURCE NEEDS............................................................... 18

5. EMPLOYMENT NEEDS AND RADIATION EXPOSURE.............................................19

5.1 EMPLOYMENT DURING CONSTRUCTION/INSTALLATION OF THE PLUTONIUM POLISHING ADD-ON FACILITY .............................................

5.2 EMPLOYMENT NEEDS DURING OPERATIONS................................................. 19

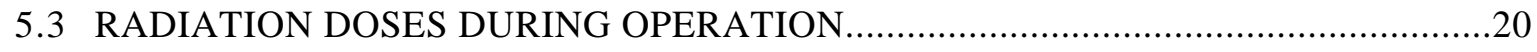

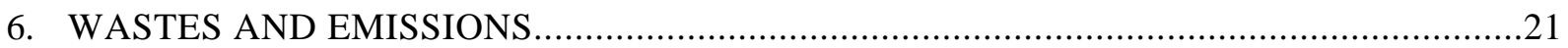

6.1 WASTES GENERATED FROM CONSTRUCTION ...............................................21

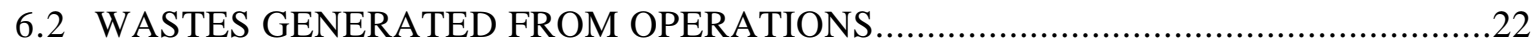

6.3 AIR EMISSIONS FROM CONSTRUCTION/INSTALLATION ..................................23

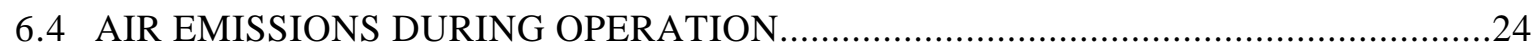

6.5 RADIOACTIVE RELEASES DURING OPERATION ..............................................25 


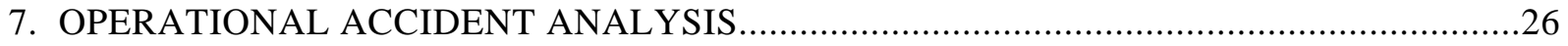

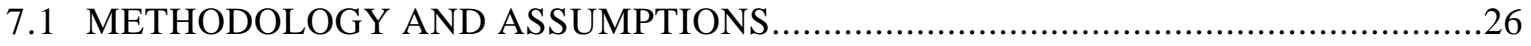

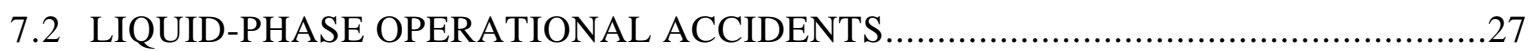

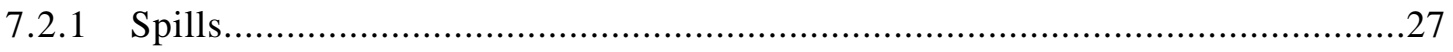

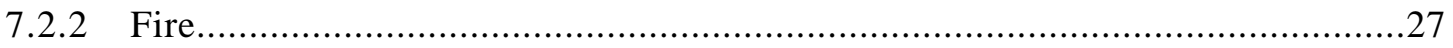

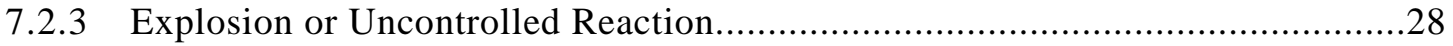

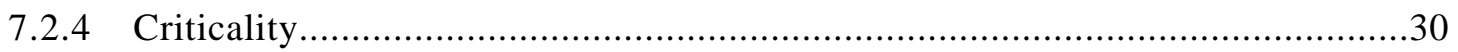

7.2.5 Beyond-Design Basis Earthquake (Total Collapse of Building)........................... 31

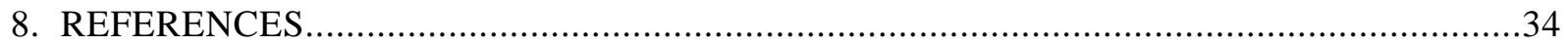




\section{LIST OF FIGURES}

Fig. 2.1(a) First level - plutonium polishing layout......................................................

Fig. 2.1(b) Second level — plutonium polishing layout..................................................

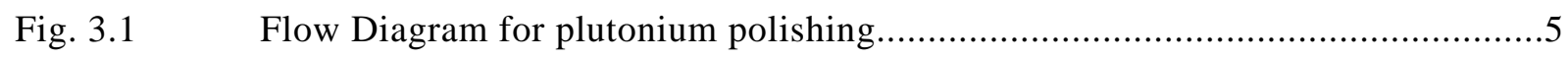

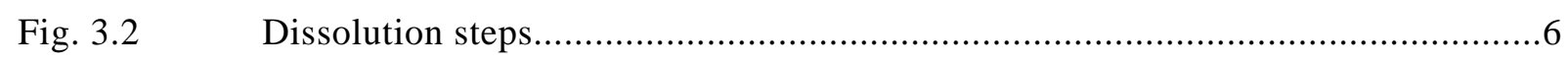

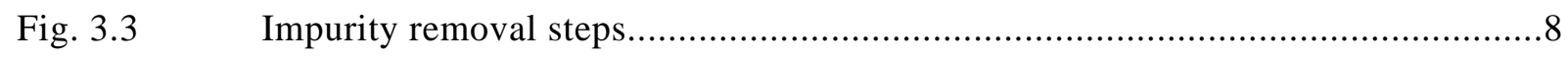

Fig. $3.4 \quad$ Oxide conversion steps........................................................................ 10

Fig. 3.5 Liquid waste handling and acid recovery process steps...............................12

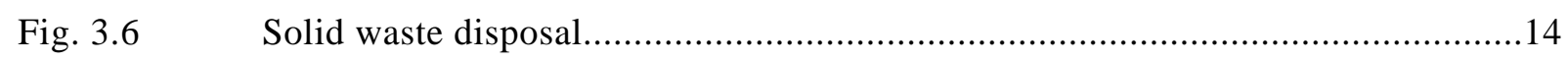




\section{LIST OF TABLES}

Table 4.1 Resource needs for construction/installation of plutonium polishing facilities.

Table 4.2 Resource needs during operation of plutonium processing activities

Table 5.1 Employment during construction/installation of plutonium polishing

facilities

Table 5.2 Annual employment requirements during operation of plutonium polishing activities.

Table 5.3 Radiation doses (whole body) (CEDE) to involved plutonium polishing workers during operation.

Table 6.1 Estimated waste generated during construction/installation of plutonium polishing facilities

Table 6.2 Estimated waste generated from operation of the plutonium polishing activities

Table 6.3 Air emissions from construction/installation of plutonium polishing facilities.

Table 6.4 Air emissions from operation of plutonium polishing processes. 24

Table 6.5 Radioactive releases during operation of plutonium polishing facilities .25

Table 7.1 Source term for a criticality of $5 \times 10^{17}$ fissions........ 32

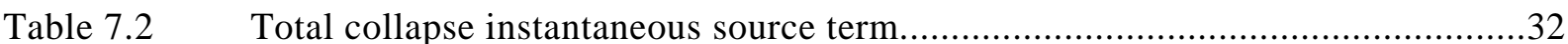

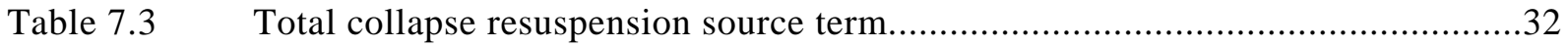

Table 7.4 Radionuclides released from postulated accident scenarios. 33 


\section{INTRODUCTION AND SCHEDULE}

The intent of this document is to provide early access to key process and environmental information. The primary source document for this technical report is the "Environmental Data Report for Generic Site Add-On Facility for Plutonium Polishing", prepared to support the Surplus Plutonium Disposition Environmental Impact Statement.

The purpose of this report is to provide environmental data and reference process information associated with incorporating plutonium polishing steps (dissolution, impurity removal, and conversion to oxide powder) into the generic-site Mixed-Oxide Fuel Fabrication Facility (MOXFF). The incorporation of the plutonium polishing steps will enable the removal of undesirable impurities, such as gallium and americium, known to be associated with the plutonium. Moreover, unanticipated impurities can be removed, including those that may be contained in (1) poorly characterized feed materials, (2) corrosion products added from processing equipment, and (3) miscellaneous materials contained in scrap recycle streams. These impurities will be removed to the extent necessary to meet plutonium product purity specifications for MOX fuels.

Incorporation of the plutonium polishing steps will mean that the Pit Disassembly and Conversion Facility (PDCF) will need to produce a plutonium product that can be dissolved at the MOXFF in nitric acid at a suitable rate (sufficient to meet overall production requirements) with the minimal usage of hydrofluoric acid, and its complexing agent, aluminum nitrate. This function will require that if the PDCF product is plutonium oxide powder, that powder must be produced, stored, and shipped without exceeding a temperature of $600^{\circ} \mathrm{C}$. 


\section{FACILITY DESCRIPTION}

The space within which the plutonium polishing steps-dissolution, impurity removal, conversion to oxide, and nitric acid recovery-would be housed is illustrated in Fig. 2.1. The floor space required is approximately $21.3 \mathrm{~m}$ by $45.7 \mathrm{~m}$ on each of two levels, making a total of $\sim 1950 \mathrm{~m}^{2}$ $\left(21,000 \mathrm{ft}^{2}\right)$. This processing space must be built as "hardened space" to the standards required for processing special nuclear material (SNM).

The architect-engineer for the MOXFF base facility will be responsible for revising the base facility layout to add-in and integrate the plutonium polishing process space requirements (as shown in Fig. 2.1) to maximize the operating efficiency of the entire facility. No major utility additions will be required; however, the incremental addition for utility services, heating, ventilation, and air-conditioning (HVAC) systems, the control room, and analytical laboratory should require no more than $500 \mathrm{~m}^{2}$ if efficient integration of these requirements into the base facility design is achieved. Thus, the additional "hardened space" required for the operating and support area would be $1950 \mathrm{~m}^{2}+500 \mathrm{~m}^{2}$, or a total of approximately $2500 \mathrm{~m}^{2}\left(27,000 \mathrm{ft}^{2}\right)$, or less if efficient design is achieved.

The construction requirements for the MOXFF base facility would need to be increased proportionately to the additional space requirements for the polishing facility. The increases will be estimated as follows:

\begin{tabular}{|c|c|c|}
\hline $\begin{array}{c}\text { MOXFF base facility } \\
\text { hardened area, } \mathbf{~ m}^{\mathbf{2}}\end{array}$ & $\begin{array}{c}\text { Add-on plutonium polishing facility } \\
\text { hardened area, } \mathbf{~ m}^{\mathbf{2}}\end{array}$ & $\begin{array}{c}\text { Increase } \\
\mathbf{\%}\end{array}$ \\
\hline $11,150^{2}$ & 2,500 & 22 \\
\hline
\end{tabular}

The construction data supplied in the data report for the MOXFF vary with the conditions at each site. Thus, to provide estimated values for construction/installation of the add-on plutonium polishing facilities at a generic site, the add-on factor previously described will be applied to the values given in the Environmental Data Report for the MOXFF located at Pantex, ${ }^{2}$ where the base plant would be a new facility.

"Nonhardened" space must also be increased. Offices, change rooms, and the lunch room will be provided by the MOXFF base facility. These nonhazardous areas may have to be increased in size by $24 \%$ for the MOXFF (see Sect. 5.2 for calculation) to accommodate the plutonium polishing staff. The nonhardened support areas for the MOXFF base facility have been estimated to be 929 to $1,858 \mathrm{~m}^{2}$. Thus, the nonhardened area for the add-on plutonium polishing facility would be an additional $24 \%$, or 223 to $446 \mathrm{~m}^{2}$, or an average of $335 \mathrm{~m}^{2}$. In summary, the total added space for the plutonium polishing activities is as follows:

$\begin{array}{ll}\text { Hardened Space } & \leq 2,500 \mathrm{~m}^{2}\left(\leq 27,000 \mathrm{ft}^{2}\right) \\ \text { Nonhardened Space } & \sim 335 \mathrm{~m}^{2}\left(\sim 3,600 \mathrm{ft}^{2}\right)\end{array}$




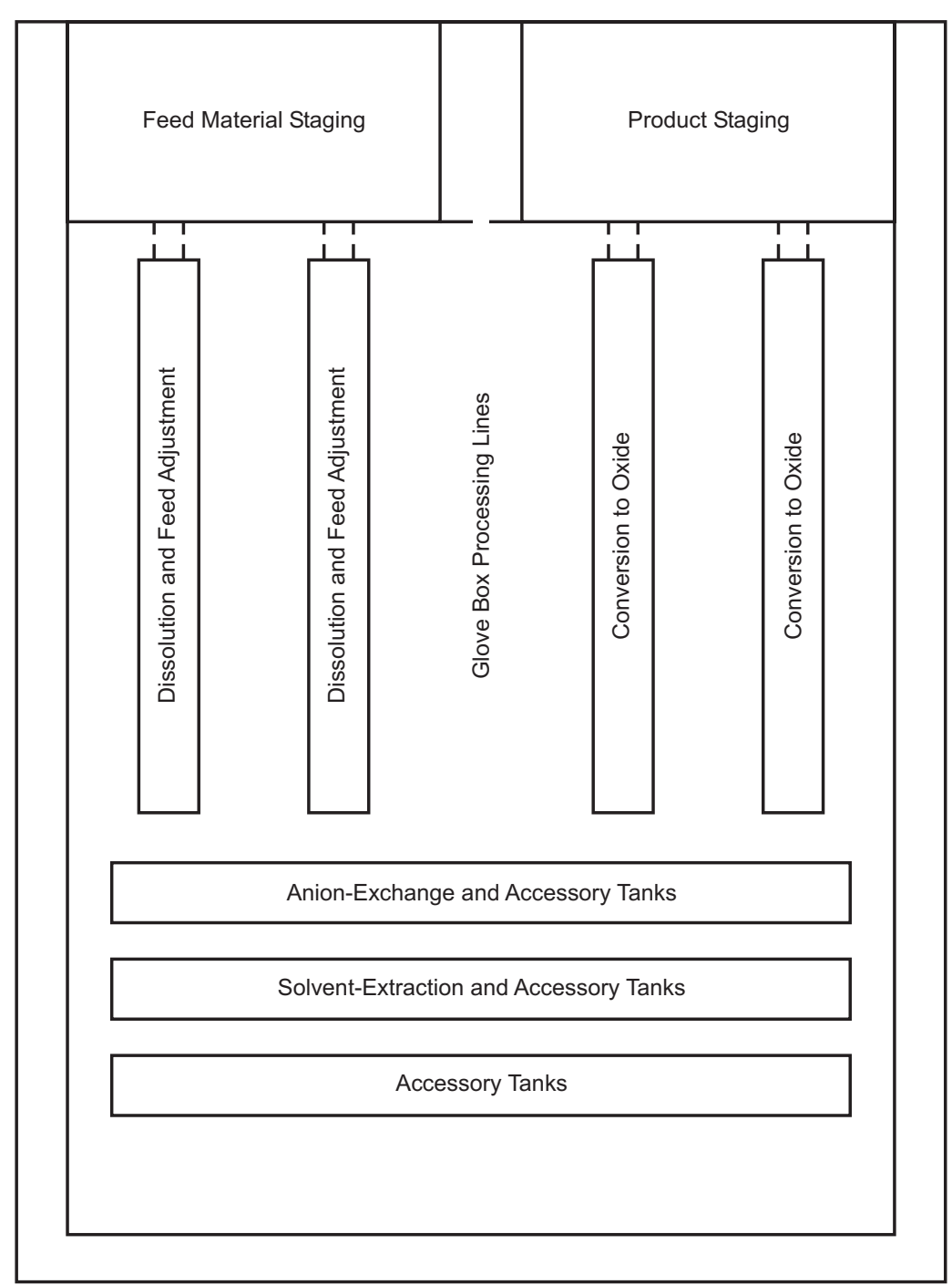

Fig. 2.1(a) First Level - Plutonium Polishing Layout $\left(\sim 21.3 \times 45.7 \mathrm{~m} \simeq 975 \mathrm{~m}^{2}\right)$

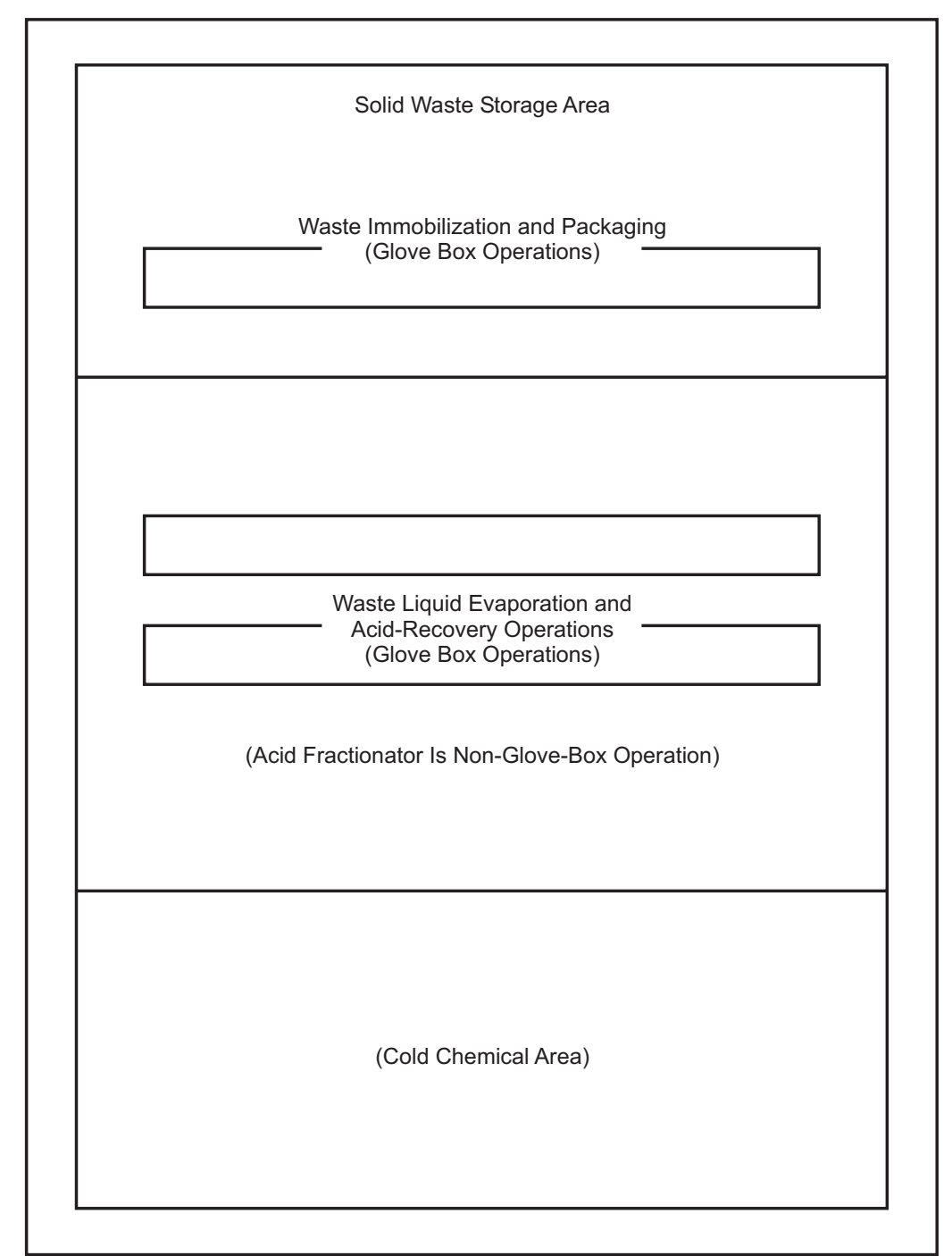

Fig. 2.1(b) Second Level - Plutonium Polishing Layout $\left(\sim 21.3 \times \sim 45.7 \mathrm{~m} \simeq 975 \mathrm{~m}^{2}\right)$ 


\section{PROCESS DESCRIPTION}

As shown in Fig. 3.1, the process steps that encompass plutonium polishing include (1) catalyzed dissolution of the plutonium in nitric acid, (2) removal of impurities by means of chemical separations (solvent extraction and/or anion exchange), and (3) conversion of the plutonium to oxide powder.

Provisions for plutonium scrap recycle are provided at each process step. Alternatively, scrap which is not amendable to recycle may be sent to the immobilization facility for disposition. Also included is the supporting step in which approximately $99 \%$ of the nitric acid is recovered and recycled. Annual values for the incremental inputs, outputs, and resulting waste streams are given on a process-level in Fig. 3.1.

\subsection{DISSOLUTION}

Figure 3.2 shows the reference dissolution steps. Plutonium feed to the dissolution step is assumed to be HYDOX - produced oxide powder. The HYDOX process and any subsequent storage and/or shipping conditions should be limited to a maximum temperature of $600^{\circ} \mathrm{C}$ to minimize the amount of hydrofluoric acid catalyst and its complexing agent, aluminum nitrate, that is required to dissolve the plutonium in nitric acid at a satisfactory rate sufficient to meet overall production requirements. (Some surplus plutonium may be stabilized at a higher temperature, thus requiring larger amounts of hydrofluoric acid and aluminum nitrate and a relatively slower rate of dissolution; however, the amount of material requiring this special treatment is expected to be a small portion of the weapons plutonium.) The reference dissolution process includes the use of hydrofluoric acid and aluminum nitrate which subsequently become wastes.

Plutonium feedstock would be transferred from interim storage to a feed preparation glove box before initiation of the dissolution step. Once inside the feed preparation glove box the plutonium would be weighed and transferred in $2 \mathrm{~kg}$ amounts to one of the dissolver glove box lines. The plutonium batch would be charged to a dissolver tank and dissolved in approximately $20 \mathrm{~L}$ of $12 \mathrm{M}$ nitric acid and $0.05 \mathrm{M}$ hydrofluoric acid at near boiling temperature to produce a final plutonium concentration of about $100 \mathrm{~g} / \mathrm{L}$. Off-gas produced during dissolution will pass through a condenser which returns the condensable vapors to the dissolver. After $4 \mathrm{~h}$, the dissolver is cooled to $<50^{\circ} \mathrm{C}$ and aluminum nitrate is added to obtain an aluminum to fluoride mole ratio of 2 to 1 . The aluminum preferentially forms a complex with the fluoride minimizing the formation of undesirable plutonium fluoride complexes, and also prevents excessive corrosion of process piping in subsequent process steps. (Even though the fluoride acts as a catalyst and is not consumed in the dissolution process, the fluoride in each batch remains in the dissolver product solution along with the plutonium and must be replaced for the next batch.) Finally, the dissolver solution is filtered and transferred to a Run Tank. Solids removed from the solution are recycled to the dissolver to await the next dissolution batch. Periodically, insoluble solids $(\sim 3 \mathrm{~kg} / \mathrm{year}$, or $2.5 \times 10^{-3} \mathrm{~m}^{3}$ ) must be removed as transuranic (TRU) waste. 


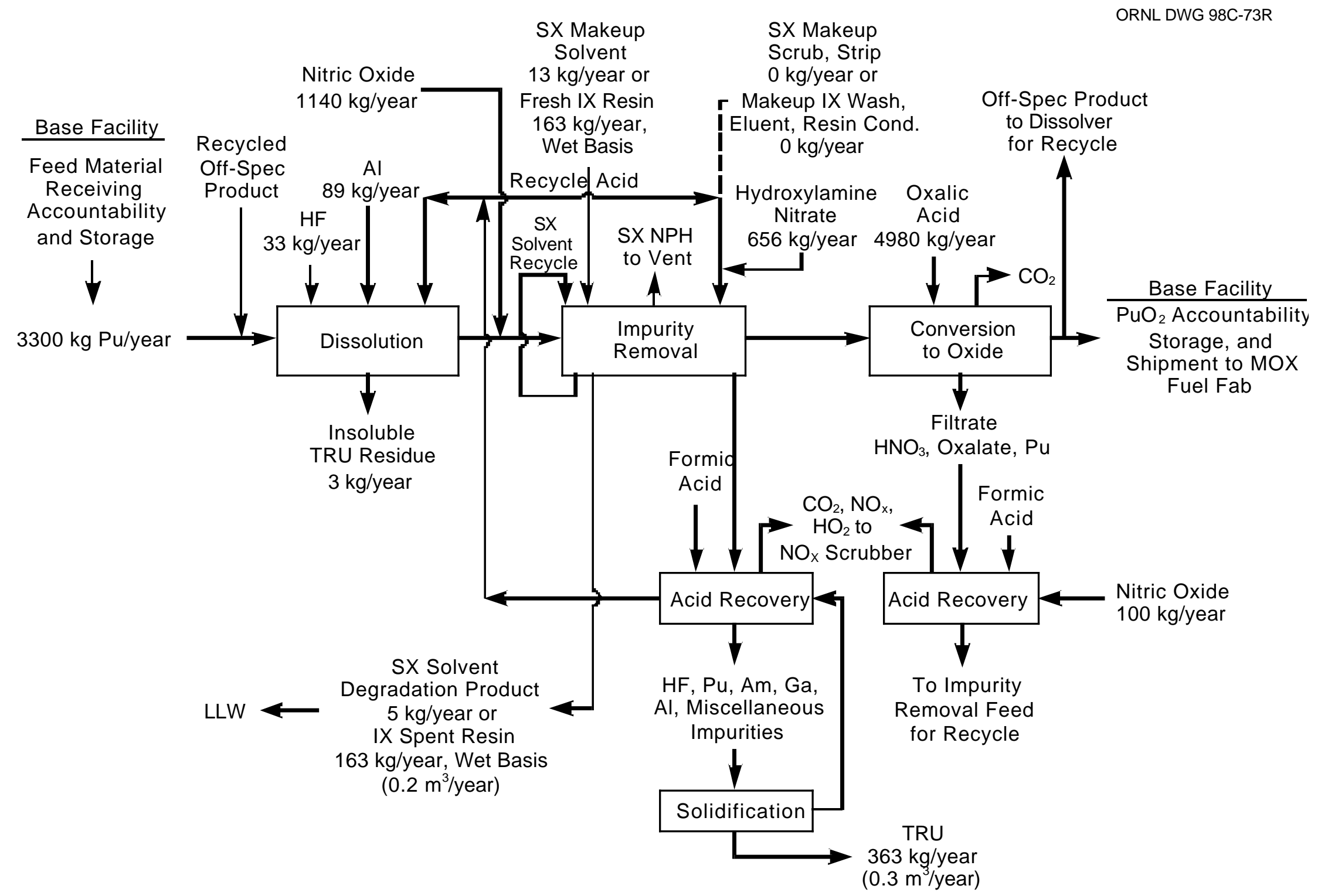

Fig. 3.1 Flow diagram for plutonium polishing. 
ORNL DWG 98C-75

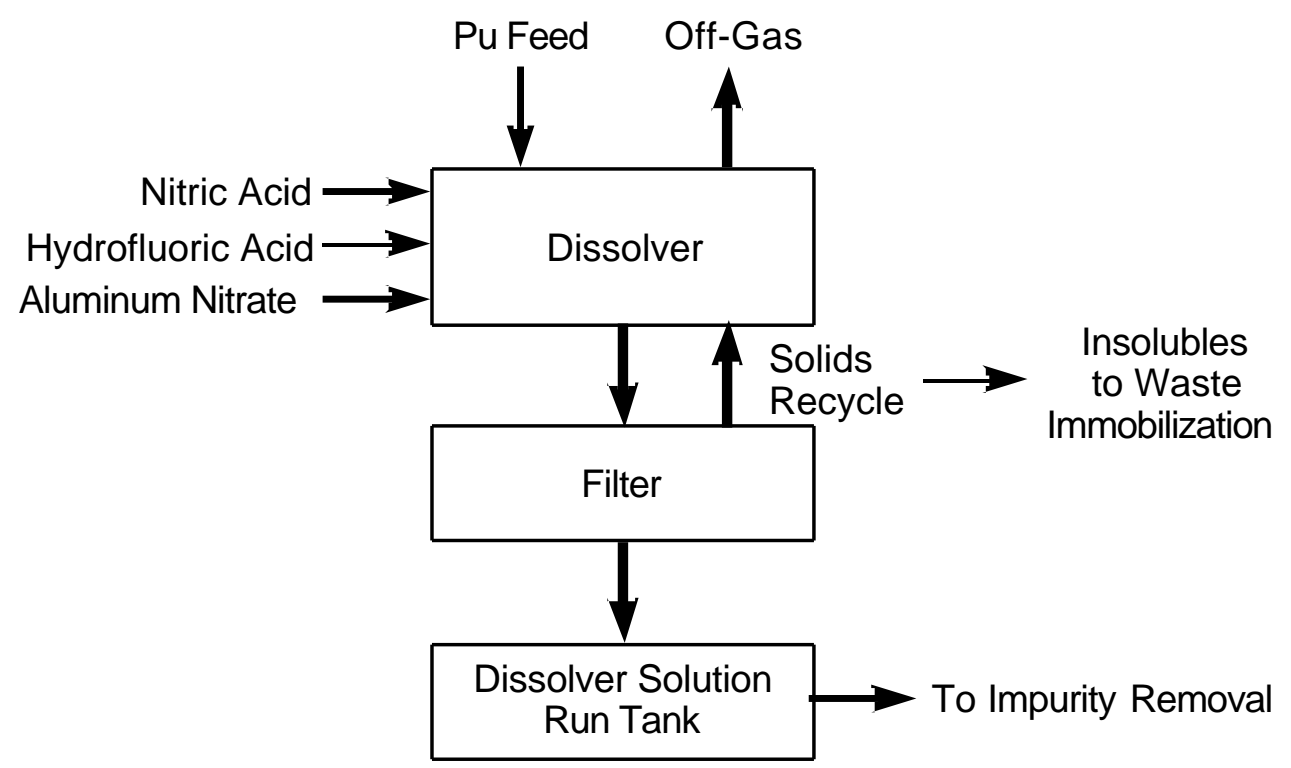

Fig. 3.2 Dissolution steps. 


\subsection{IMPURITY REMOVAL}

Figure 3.3 shows the impurity removal steps. The capability to use either solvent extraction or anion exchange to accomplish the impurity removal provides the versatility needed to meet varying demands that are likely to be encountered. The continuous solvent extraction process will enable larger capacity needs to be met more efficiently, whereas multiple batch anion exchange runs can be used effectively for lower capacity needs.

The technical team considered the merits of both solvent extraction and ion exchange technologies to provide the desired impurity removal capability. Either technology can be made to work but each is best applied in somewhat different scenarios. Small lots or intermittent operation can best be performed using ion exchange. For longer campaigns, a continuous solvent extraction operation would reduce manpower requirements and associated exposure, waste, and potential for human error.

The impurity removal step is a small part of the overall process and facility. Environmental impacts are calculated sizing both technologies to accomplish the goal of processing 3.3 MT plutonium per year with the intention that actual operation will be performed using ion exchange part of the time, and solvent extraction part of the time. The projected environmental impacts in terms of construction or operating resources, waste, risk, exposure, accident potential, and other measures of impact, would not be appreciably reduced by including only one of the technologies. The inclusion of both technologies will result in the overall minimum impact and cost over the life of the program by providing the flexibility to optimize the process to fit the specifics of varying day-to-day operations.

For the solvent extraction process, the dissolver solution will be adjusted to an acidity of 3 to $4 \mathrm{M}$, and the solution will be treated with nitric oxide gas at 60 to $80^{\circ} \mathrm{C}$ to ensure that the plutonium is in the tetravalent state. The adjusted feed solution is fed to a series of compact centrifugal contactors. Typically 8 contactors will be used for extraction, 4 for scrubbing impurities from the solvent extract, and 12 for stripping the plutonium from the solvent extract into an aqueous product solution. The product solution will have the appropriate concentrations $\left(\sim 0.5 \mathrm{M} \mathrm{HNO}_{3}\right.$ and $40 \mathrm{~g} \mathrm{Pu} / \mathrm{L}$ ) for feeding to the subsequent oxide conversion process. Stripped solvent is periodically washed to remove degradation products and is recycled for reuse. Typically four contactors will be used for solvent washing with water, hydroxylamine, and nitric acid to remove degradation products (dibutyl and monobutyl phosphoric acid). Another four contactors (two for each stream) will be used for a diluent (n-paraffin hydrocarbon) wash of the aqueous waste streams and aqueous plutonium product stream to minimize solvent losses from entrainment and solubility.

Each contactor is $5.5 \mathrm{~cm}$ in diameter and consists of a mixing chamber, centrifugal separator, a weir for aqueous/solvent interface control, mixer drive motor assembly, and interstage piping. In each contactor, the aqueous and solvent are mixed and then separated by centrifugal force. The high speed separation allows for much higher throughput than can be achieved by comparable size mixer-settler contactors or ion exchange columns. The solvent extraction system will have a capacity to process plutonium at the rate of $1 \pm 0.5 \mathrm{~kg}$ plutonium/hour. In addition, the low 


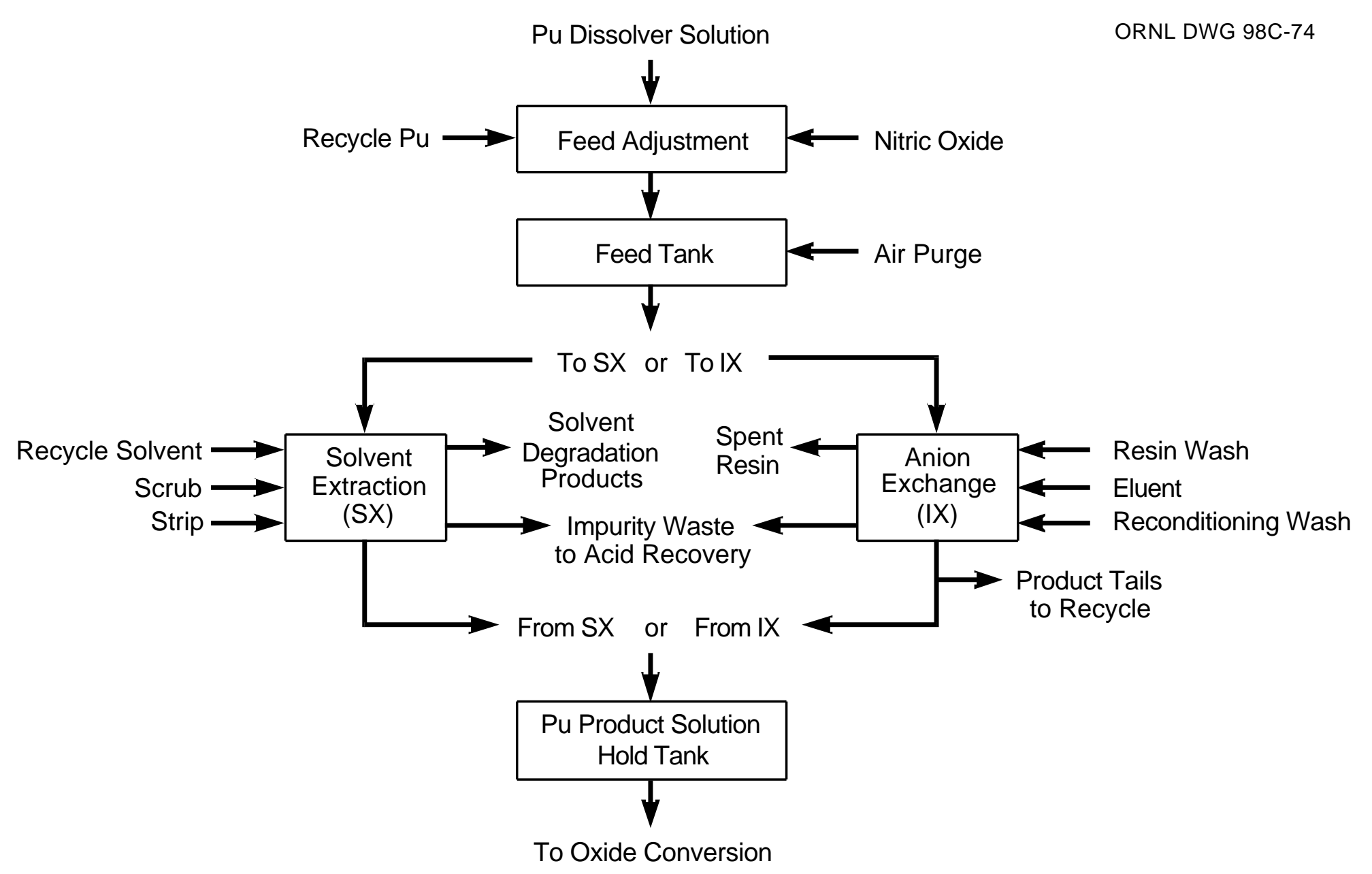

Fig. 3.3 Impurity removal steps. 
holdup volume (500 mL maximum) and the small diameter in each contactor provides geometrically favorable design suitable for high concentrations of fissile materials. The compact centrifugal contactors are normally arranged in a group of four ("four-packs") and each fourpack is contained in a $0.16 \mathrm{~m}^{2}$ square array; thus, all 32 contactors will occupy an area of about $1.3 \mathrm{~m}^{2}$ in size.

Multiple anion exchange columns will be provided. Each column will be $\sim 15 \mathrm{~cm}$ diameter by $1.8 \mathrm{~m}$ long and will contain $\sim 30 \mathrm{~L}$ of Reillex HPQ resin (40 to 70 mesh size). Each column will have the capacity to process $1 \mathrm{~kg}$ of plutonium per batch. In a typical batch, the feed (dissolver solution) is adjusted to 7 to $8 \mathrm{M} \mathrm{HNO}_{3}-100 \mathrm{~g} / \mathrm{L}$ plutonium and is treated with nitric oxide gas at 60 to $80^{\circ} \mathrm{C}$ to ensure that the plutonium is in the tetravalent state. After the valence adjustment is completed, the feed solution will be air-sparged to remove nitrite ion which could cause damage to the ion-exchange resin. The adjusted feed solution is transferred through a resin column to load the plutonium. The resin is then washed with $7 \mathrm{M} \mathrm{HNO}_{3}$ to remove impurities. Plutonium is then eluted from the resin with dilute nitric acid $(\sim 0.4 \mathrm{M})$ containing sufficient hydroxylamine nitrate to reduce the plutonium to the trivalent state. Dilute tails are collected for recycle and the concentrated plutonium product will have the appropriate concentrations $\left(\sim 0.5 \mathrm{M} \mathrm{HNO}_{3}\right.$ and $30 \mathrm{~g} / \mathrm{L}$ plutonium) for feeding to the subsequent oxide conversion process.

Both the solvent extraction and anion exchange process produce an aqueous acidic waste solution containing the separated impurities (gallium, americium, aluminum, fluorine, and other miscellaneous materials). Other chemical additions decompose to gaseous products, thereby generating no additional solid wastes. This waste solution is treated by evaporation to recover nitric acid and the concentrated impurities are solidified for disposal as TRU waste.

\subsection{CONVERSION TO OXIDE}

Following impurity removal, the plutonium is converted from nitrate solution to oxide powder by means of the oxalate precipitation/filtration/calcination process. The oxide conversion steps are shown in Fig. 3.4. The process is based on multiple batch processing as currently practiced at the Savannah River Site (SRS), Los Alamos National Laboratory (LANL), and Oak Ridge National Laboratory (ORNL). However, continuously operated equipment has been operated successfully at the Hanford Site for the entire process and for calcination at ORNL. The continuous processes offer several advantages, especially for large scale (multitons per year) production, and should be evaluated during process design studies.

Plutonium product solutions from the impurity removal step are transferred into precipitation feed adjustment tanks where the plutonium valence is adjusted. The adjusted feed solution will be fed into one of several batch multistage precipitation tanks. Oxalic acid $(0.9 \mathrm{M})$ will be added to the precipitator to maintain an excess of $0.1 \mathrm{M}$ oxalate in the slurry to ensure complete precipitation and crystal growth. The slurry will be mixed for $1 \mathrm{~h}$ and allowed to settle for $0.5 \mathrm{~h}$. Then the precipitate slurry will be transferred via vacuum through filter boats which have stainless steel or platinum mesh filters in the bottom. 


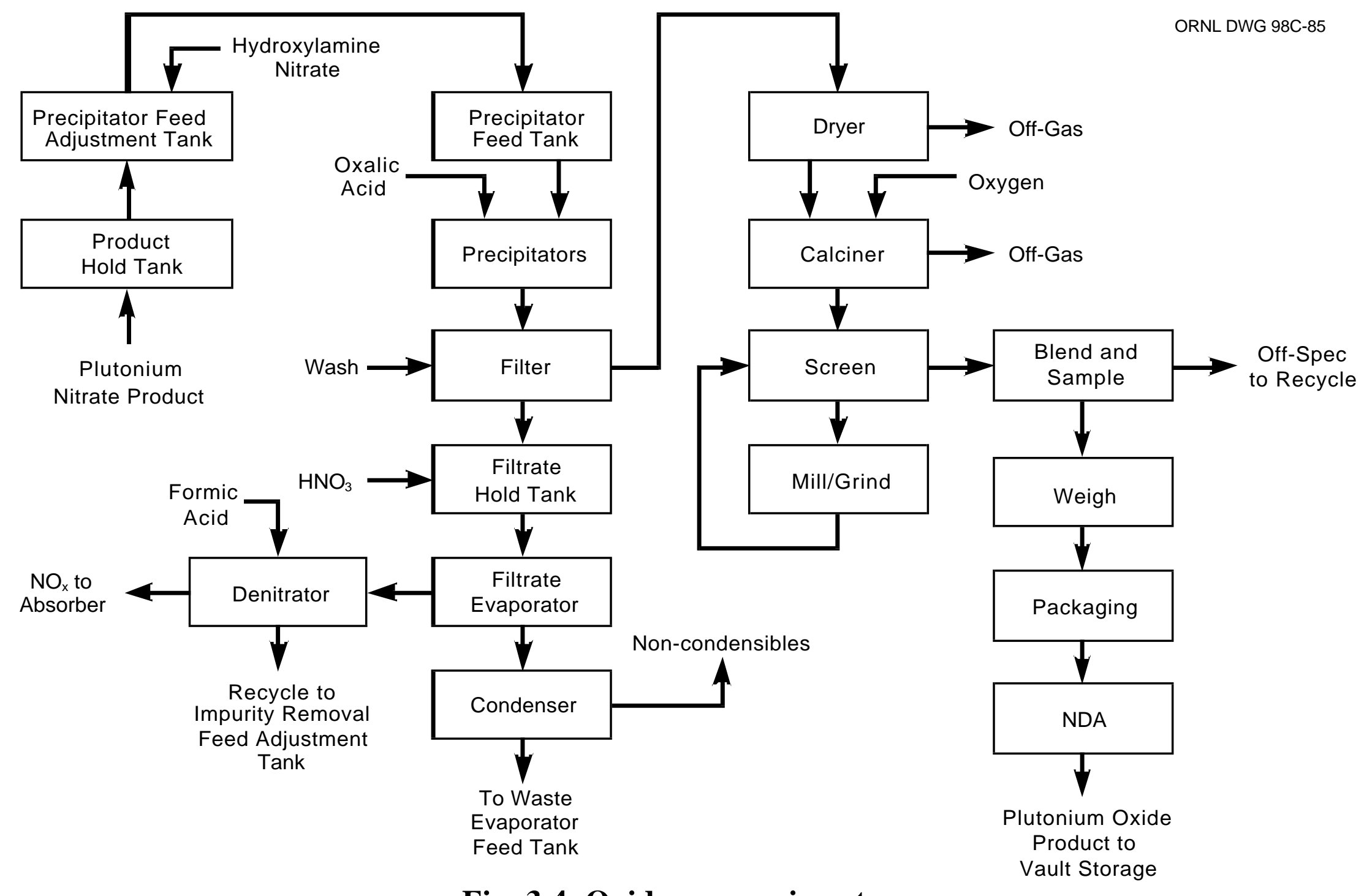

Fig. 3.4 Oxide conversion steps. 
Filtrate solution from the filter station will be (1) collected in surge tanks, (2) treated by sparging with nitric oxide gas to decompose residual hydroxylamine nitrate, (3) acidified to dissolve oxalate solids, and (4) transferred through a polishing filter to the continuous filtrate evaporator. The filtrate solution will be reduced in volume and the nitric acid concentration will be increased to approximately 8 molar in the bottoms. Any plutonium oxalate will be converted to plutonium nitrate and the oxalic acid will be destroyed by the boiling nitric acid. Overheads from the concentrator will be sent to the acid recovery fractionation; the bottoms will be denitrated, using formic acid as described below. The denitrated filtrate will be recycled to the impurity removal feed adjustment tank for plutonium recovery.

The wet cake is washed with a dilute oxalic/nitric acid $(0.1 \mathrm{M} / 0.5 \mathrm{M})$ solution, and the filter boat containing the washed cake is transferred to a furnace for air drying at $125^{\circ} \mathrm{C}$ for $2 \mathrm{~h}$ to reduce the moisture content below $0.5 \%$. The dried cake is then calcined to an oxide in the furnace at $600^{\circ} \mathrm{C}$ for $5 \mathrm{~h}$. The furnaces can be double batched (two precipitator batches) to increase throughput. The cake wash is combined with the filtrate solution for plutonium and acid recovery. Periodic flushing of the filter boats is performed to remove plating of plutonium compounds and reduce filter pluggage. The boat flush solution is also combined with the filtrates and cake wash solution.

The oxide powder leaving the dryer-calciner will be fed, by gravity, to a vibrating screen which will separate product powder from oversize material. The oversize stream will be fed to a ball mill grinder for size reduction and then recycled to the screen. The product from the powder screen will be collected in a hopper. Batch blenders will be loaded from the hopper for blending and sampling of the product. Storage canisters will be loaded from the blender. The storage canisters will be loaded into a storage container using a bagless transfer system. The storage container will be placed in an interim storage vault until it is transferred for final disposition.

All powder handling will be performed in enclosed equipment to contain the oxide dust. Batch loading between equipment will be done through powder valves that can isolate the equipment from the atmosphere of the process containment glove box.

\subsection{LIQUID WASTE HANDLING AND ACID RECOVERY}

The liquid waste handling and acid recovery process steps are shown in Fig 3.5. This system is similar to that used at SRS. However, process refinements and improvements may be possible. Raffinate and washes from the impurity removal operations and condensate from the oxalate filtrate evaporator will be transferred to a waste evaporator feed tank and evaporated to an acidity of $8 \mathrm{M}$. The evaporator condensate will be fed to an acid fractionating column to produce concentrated acid and acidified water for process reuse.

The evaporator concentrate will be chemically denitrated, using formic acid, via the following reaction:

$$
\mathrm{HNO}_{3}+1.5 \mathrm{HCOOH}=\mathrm{NO}+1.5 \mathrm{CO}_{2}+2 \mathrm{H}_{2} \mathrm{O} .
$$




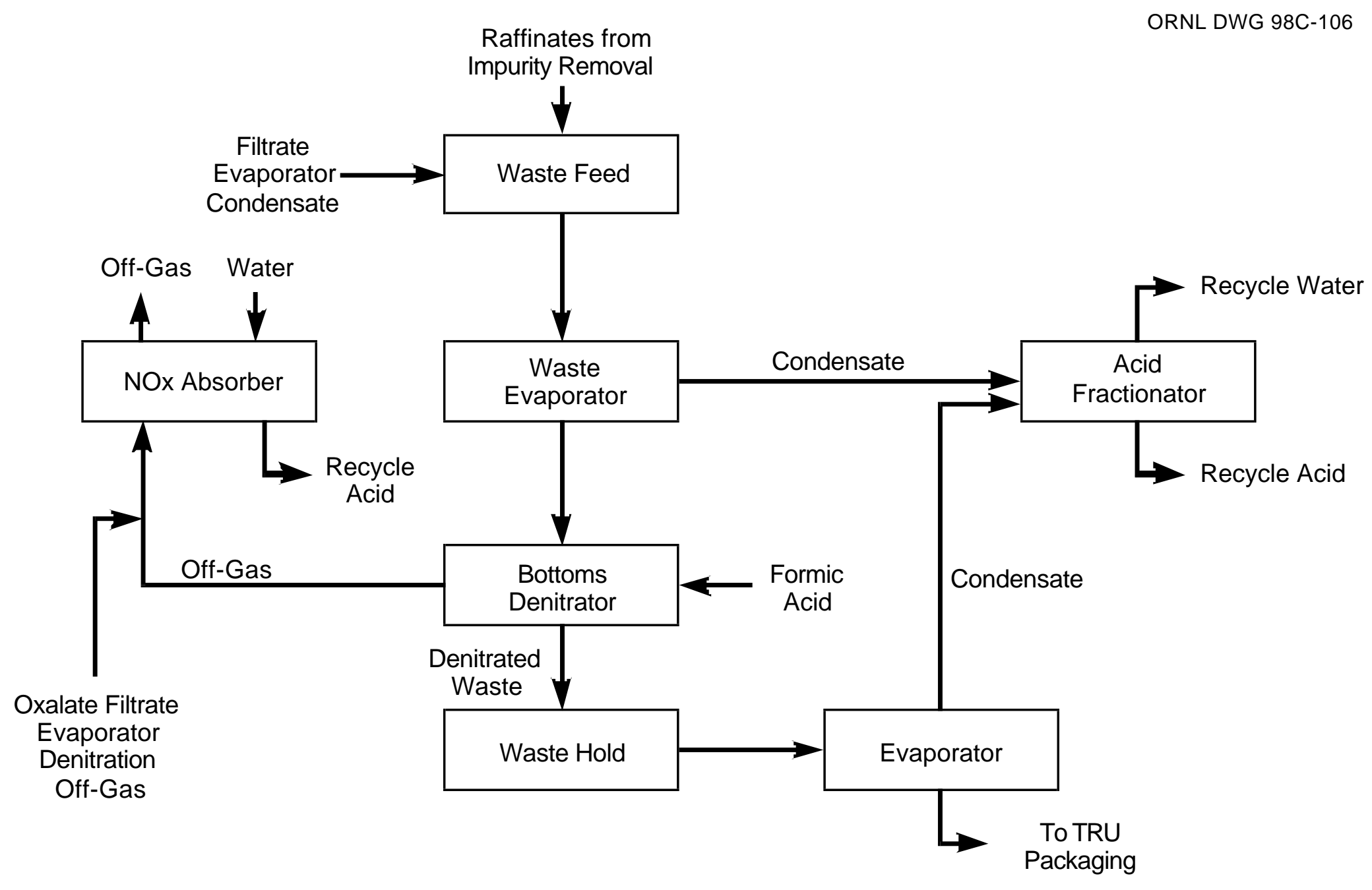

Fig. 3.5 Liquid waste handling and acid recovery process steps. 
Off-gas from the denitrator will be sent to a scrubber where the nitric oxide gas is absorbed and converted to concentrated nitric acid. Nonabsorbed gases, including all of the $\mathrm{CO}_{2}$ and $<5 \%$ of the $\mathrm{NO}_{\mathrm{x}}$, will be vented.

The denitrated waste solution concentrate will be evaporated further to remove the remaining water and nitric acid, producing a solid TRU waste containing the americium, gallium, aluminum, other miscellaneous impurities, and most of the fluorine. The use of a fluoride trap (containing, for example, zirconium oxynitrate) in the off-gas system may be necessary to ensure that the recycle acid does not contain excessive hydrofluoric acid.

\subsection{SOLID WASTE TREATMENT}

Solid waste disposal flow is shown in Fig. 3.6. Solid waste generated from process operations includes glove box gloves, failed equipment, tools, wipes, and filter elements. These materials will be removed from the process glove box lines and transferred to the waste packaging glove box (WPG). Nonprocess materials will be wiped or immersed in acid decontamination solution to remove residual plutonium. The waste materials will then be dried and removed from the WPG for packaging and assay. Items exceeding the criteria for disposal as low-level radioactive waste (LLW) (containing $>100 \mathrm{nCi}$ of transuranic isotopes per gram of waste matrix) will be packaged as TRU waste. These wastes are expected to be in proportional volume to those wastes produced in other glove box operations within the base facility.

Lead-lined gloves from process glove boxes that do not meet TRU waste criteria will be segregated for disposal as mixed LLW. Glove box roughing filters and high-efficiency particulate air (HEPA) filters will likely contain quantities of plutonium oxide which should be recovered to reduce the actinide content of the waste. The filters will be placed in a mechanical vibration device to dislodge oxide from the filter elements. Any recovered plutonium solids will be packaged and removed from the glove box for recycle. Decontamination solution will also be sampled periodically and can be recycled for plutonium recovery.

Degraded resin from the process ion exchange columns must be replaced periodically to maintain process efficiency. The resin is displaced from the column to a stainless steel canister, and chemically stabilized in the canister. When the heat of reaction has dissipated and the resin is dry, the canister is sealed, the package assayed, and disposed as LLW waste. Assuming that the anion exchange system could be used to polish the entire 3.3 MT of plutonium each year, the resin waste would be only $163 \mathrm{~kg} / \mathrm{year}$, wet basis $\left(0.2 \mathrm{~m}^{3} /\right.$ year $)$.

Solvent degradation products (dibutyl and mono butyl phosphate) from the solvent extraction operation are removed from the solvent by scrubbing with aqueous hydroxylamine, which is subsequently decomposed by sparging with nitric oxide. This waste stream is expected to be very small, containing less than $5 \mathrm{~kg}\left(\sim 0.004 \mathrm{~m}^{3}\right) /$ year, even when the solvent extraction is used for the entire year.

As shown in Fig. 3.1, the solidified TRU sludgeis expected to contain about $363 \mathrm{~kg} / \mathrm{year}$, including ${ }^{241} \mathrm{Am}$, gallium, aluminum, fluorine, and miscellaneous impurities removed from the plutonium 
ORNL DWG 98C-84

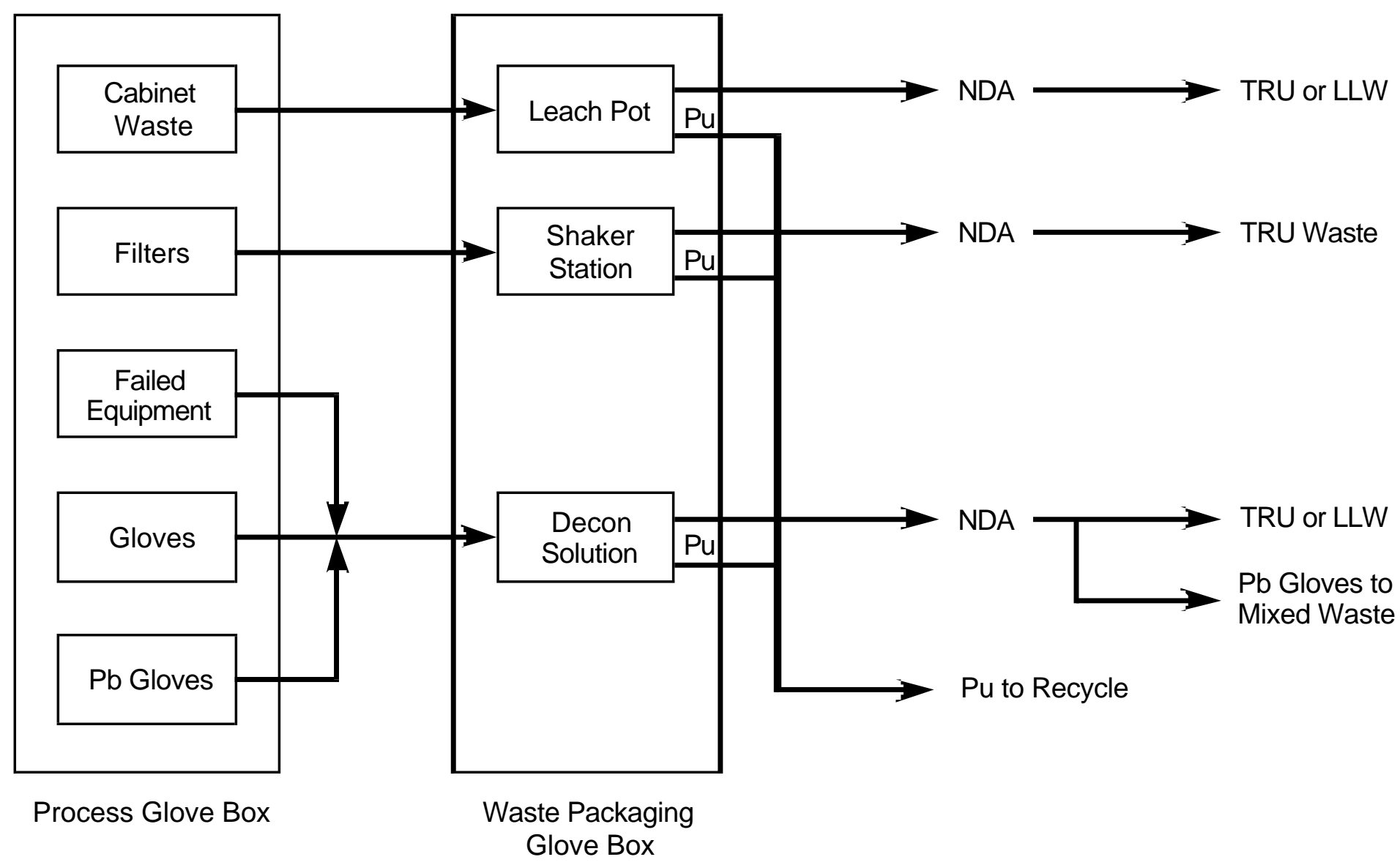

Fig. 3.6 Solid waste disposal. 
feed solution, including less than $10 \mathrm{~kg} /$ year of plutonium loss. This waste material will be relatively dense, such that the volume expected is approximately $0.3 \mathrm{~m}^{3} / \mathrm{year}$. While the volume of this sludge is small, the TRU activity (number of curies of ${ }^{241} \mathrm{Am}$ ) will likely limit the loading to larger volume for shipment to the Waste Isolation Pilot Plant (WIPP) (per WIPP WAC Rev. 5, which specifies a maximum number of curies per waste drum). This can be avoided by disposing the TRU sludge via the immobilization process.

\subsection{PROCESS REFINEMENT ACTIVITIES}

Although the process steps comprising plutonium polishing have all been used in previous applications, process refinements and improvements may be needed to adapt the processes to the application of weapons plutonium disposition. These efforts may be needed to ensure that the process steps can be efficiently operated and integrated to achieve the goals of the Fissile Materials

Disposition Program. Several of these process refinements and improvements are described in the following sections.

\subsubsection{Dissolution}

Integration tests of the HYDOX process with the aqueous dissolution may be necessary to ensure that the weapons plutonium can be dissolved satisfactorily in nitric acid at a rate sufficient to meet production needs and to eliminate, or at least minimize the amounts of hydrofluoric acid and its complexing agent, aluminum nitrate, that are required.

\subsubsection{Impurity Removal}

Removal of typical impurities, such as gallium, americium, and aluminum from the plutonium product is expected to be by factors of $10^{4}$ to $10^{5}$ in Purex solvent extraction or in nitrate anion exchange. In addition, uncomplexed fluoride, if present in excessive concentration, would need to be removed by means of the impurity removal step. The actual achievable decontamination factors may have to be measured or demonstrated.

\subsubsection{Plutonium Valence Adjustment}

Plutonium valence adjustment by means of sparging with nitric oxide gas can be successfully carried out. However, integration of this step with an $\mathrm{NO}_{\mathrm{x}}$ scrubber to recover excess nitric acid may need to be demonstrated.

\subsubsection{Waste Evaporation}

Acid wastes from impurity removal operations will contain aluminum, fluorine, gallium, americium, and other miscellaneous impurities in dilute concentrations. Tests may be needed to determine the extent of vaporization of fluorine during the evaporation and the need and effectiveness of an fluorine absorbent in the evaporator off-gas. 


\subsubsection{Oxide Conversion}

Development and application of continuously operated process equipment may be necessary to meet the required production rates in the most efficient manner. This is especially true for the calcination furnace application, so that multiple heatup/cooldown cycles are not needed. In addition, if oxalate precipitation is used as planned, the furnace design and process conditions must produce a product with a sufficiently low carbon content.

\subsubsection{Waste Solidification}

Solidification of the aluminum, fluorine, gallium, americium wastes is planned to be carried out by means of a thermal denitration process. However, the performance of this type of process is known to be affected by the specific chemical compounds that are present. Thus, this process may need to be refined to meet this specific application.

\subsubsection{Process Control and Automation}

Efficient operation and minimization of radiation exposures to operating personnel can be accomplished by means of effective process control and automation. Selection and application of process control/automation methods and equipment may need to be demonstrated during an integrated process operation. 


\section{RESOURCE NEEDS}

\subsection{CONSTRUCTION RESOURCE NEEDS}

The values for resource needs for construction of the add-on plutonium polishing facility can be reasonably proportioned on the basis of increased space requirements to the base facility. As described in Chapter 2 the values for resource needs for the base facilities should be increased by $22 \%$ for the MOXFF. Applying this factor to the values given in the Environmental Data Report for the MOXFF located at Pantex, where the base plant would be a new facility, ${ }^{2}$ results in estimated values for the add-on plutonium polishing resource needs during construction/installation, as shown in Table 4.1.

\section{Table 4.1. Resource needs for construction/installation of plutonium polishing facilities}

\begin{tabular}{|c|c|}
\hline & MOXFF \\
\hline Space factor for polishing add-on facilities & $\pm 22 \%^{a}$ \\
\hline Resource requirement & Average annual consumption \\
\hline \multicolumn{2}{|l|}{ Utilities } \\
\hline Electricity, MWh & 890 \\
\hline Peak demand, MW & $<0.35$ \\
\hline Fuel, L & 50,160 \\
\hline \multicolumn{2}{|l|}{ Water } \\
\hline Ground, L & $2,200,000$ \\
\hline Peak demand, L/day & 10,500 \\
\hline \multicolumn{2}{|l|}{ Chemicals } \\
\hline \multicolumn{2}{|l|}{ Gases, $\mathrm{m}^{3}$} \\
\hline Oxygen & 310 \\
\hline Acetylene & 80 \\
\hline Argon & 110 \\
\hline Nitrogen & 150 \\
\hline \multicolumn{2}{|l|}{ Liquids, L } \\
\hline Phosphoric acid & 1,100 \\
\hline Demineralized. water & 1,100 \\
\hline Muriatic acid $(10 \%$, vol. $)$ & 960 \\
\hline \multicolumn{2}{|l|}{ Solids (building materials) } \\
\hline Concrete, $\mathrm{m}^{3}$ & $2,250^{b}$ \\
\hline Steel, MT & $880^{b}$ \\
\hline
\end{tabular}

${ }^{a}$ Polishing add-on factor applied to base facility values taken from Table 5.1 of Response to the Surplus Plutonium Disposition Environmental Impact Statement Data Call for a Mixed-Oxide Fuel Fabrication Facility Located at the Pantex Plant, LA-UR-97-2067, March 2, 1998. (Ref. 2)

${ }^{b}$ Values shown are totals for the construction period, rather than annual values. 


\subsection{OPERATIONS RESOURCE NEEDS}

The resource needs during operation of the plutonium polishing activities are listed in Table 4.2 below.

Table 4.2 Resource needs during operation of plutonium processing activities

\begin{tabular}{|l|c|}
\hline \multicolumn{1}{|c|}{ Resource requirement } & $\begin{array}{c}\text { Average annual } \\
\text { consumption }\end{array}$ \\
\hline Process chemicals $^{a}$ & \\
\hline Gases & \\
\hline Nitric oxide & \\
\hline Liquids & $850 \mathrm{~m}^{3}$ \\
\hline Solvent (30 vol \% tri-butyl phosphate in n-paraffin hydrocarbon) & \\
\hline Hydrofluoric acid (35\% in water) & $15 \mathrm{~L}^{c}$ \\
\hline Formic acid & $90 \mathrm{~L}$ \\
\hline Water (assuming 1\% makeup) & $81,140 \mathrm{~L}$ \\
\hline Sanitary water & $2,770 \mathrm{~L}$ \\
\hline Solids & $1,380,000 \mathrm{~L}$ \\
\hline Hydroxylamine nitrate & \\
\hline Aluminum nitrate nanohydrate & $656 \mathrm{~kg}$ \\
\hline Oxalic acid dihydrate & $1,238 \mathrm{~kg}$ \\
\hline Reillex HPQ resin (Wet basis) & $6,970 \mathrm{~kg}$ \\
\hline
\end{tabular}

${ }^{a}$ Initial inventories are as follows:

Liquids

Water

$1320 \mathrm{~L}$

Nitric acid $(70 \%$ in water) $625 \mathrm{~L}$

Solvent (30 vol \% tri-butyl phosphate in normal paraffin hydrocarbon $\quad 200 \mathrm{~L}$ $\underline{\text { Solids }}$

Reillex HPQ resin (wet basis)

$75 \mathrm{~kg}$

${ }^{b}$ Nitric oxide is used for plutonium valence adjustment and is converted to nitric acid; thus, the nitric oxide is the source of make-up nitric acid.

${ }^{c}$ These values are based on assumed operation of either the solvent extraction system or the anion exchange system for the entire year, and on the assumption that the plutonium feed will not have been treated or stored at temperatures exceeding $600^{\circ} \mathrm{C}$. 


\section{EMPLOYMENT NEEDS AND RADIATION EXPOSURES}

\subsection{EMPLOYMENT DURING CONSTRUCTION/INSTALLATION OF THE PLUTONIUM POLISHING ADD-ON FACILITY}

Employment needs during construction and installation can be reasonably proportioned to the base facilities on the basis of the added space required. As described in Chapter 2, the values for employment during construction/installation for the base facility should be increased by $22 \%$ for the MOXFF. Applying this factor to the values given in the Environmental Data Report for the MOXFF, located at Pantex, where the base plant would be a new facility, results in estimated numbers of personnel for the add-on plutonium polishing facility construction/installation, as shown in Table 5.1.

Table 5.1 Employment during construction/installation of plutonium polishing facilities

\begin{tabular}{|l|c|}
\hline & MOXFF \\
\hline \multicolumn{1}{|c|}{ Year 1} & $\pm 22 \%^{a}$ \\
\hline Space factor for polishing add-on facilities & Average annual numbers \\
\hline Craft workers & 40 \\
\hline Administrative and management & 24 \\
\hline Year 2 & \\
\hline Craft workers & 85 \\
\hline Administrative and management & 27 \\
\hline Year 3 & \\
\hline Craft workers & \\
\hline Administrative and management & 26 \\
\hline
\end{tabular}

${ }^{a}$ Polishing add-on factor applied to base facility values taken from Table 6.1 of Response to the Surplus Plutonium Disposition Environmental Impact Statement Data Call for a Mixed-Oxide Fuel Fabrication Facility Located at the Pantex Plant, LA-UR-97-2067, March 2, 1998. (Ref. 2)

\subsection{EMPLOYMENT NEEDS DURING OPERATIONS}

The employment needs during operations of the plutonium polishing activities are listed in Table 5.2 below. 
Table 5.2 Annual employment requirements during operation of plutonium polishing activities

\begin{tabular}{|c|c|c|c|c|c|}
\hline \multirow[b]{2}{*}{ Labor category } & \multirow[b]{2}{*}{$\begin{array}{c}\text { Daytime only } \\
\text { workers }\end{array}$} & \multicolumn{3}{|c|}{ Shift workers } & \multirow[b]{2}{*}{$\begin{array}{l}\text { Number of } \\
\text { operating/ } \\
\text { maintenance } \\
\text { days per year }\end{array}$} \\
\hline & & $\begin{array}{l}\text { Each } \\
\text { shift }\end{array}$ & $\begin{array}{l}\text { Total of } \\
5 \text { shifts }^{\text {a }}\end{array}$ & $\begin{array}{c}\text { Total } \\
\text { workers }\end{array}$ & \\
\hline Officials and managers & 2 & & & 2 & \\
\hline Professionals & 9 & (1) & 5 & 14 & \\
\hline Technicians & 6 & (10) & 50 & 56 & \\
\hline Office and clerical & 2 & & & 2 & \\
\hline Crafter workers & 7 & & & 7 & \\
\hline Operatives & 0 & & & 0 & \\
\hline Laborers & 2 & & & 2 & \\
\hline Service workers & 2 & & & 2 & \\
\hline Total employees & 30 & (11) & 55 & 85 & 325 \\
\hline
\end{tabular}

${ }^{\text {a }}$ Five shifts are required to operate 3 shifts/day, 7 days/week, plus 1 shift in training.

For estimation of increased space required for the lunch room, offices, and change rooms, and for increased sanitary wastes that will be generated (see Table 6.2), the increases would be proportionate to the added number of operating personnel. The increases are estimated for the MOXFF $24 \%(350+85 / 350=1.24)$.

\subsection{RADIATION DOSES DURING OPERATION}

Estimated radiation doses to plutonium polishing workers during operation are shown in Table 5.3. Efficient management and the use of automated operations would be expected to lower the doses substantially. Also, radiation doses to workers in the subsequent fuel fabrication operations will be lowered because ${ }^{241} \mathrm{Am}$ will have been removed.

Table 5.3 Radiation doses (whole body) (CEDE) to involved plutonium polishing workers during operation

Average annual dose to all involved polishing workers

500 mrem

Maximum dose to involved polishing workers

2000 mrem

Total exposure of involved polishing workers (estimated 60 workers)

30 person-rem 


\section{WASTES AND EMISSIONS}

\subsection{WASTES GENERATED FROM CONSTRUCTION}

The types and amounts of wastes generated from construction of the plutonium polishing facilities can be reasonably proportioned to the wastes generated during construction of the base facility on the basis of added space required for the add-on plutonium polishing facilities. As described in Chapter 2, the values for wastes generated during construction of the base facility should be increased by $22 \%$ for the MOXFF. Applying this factor to the values given in the Environmental Data Report for the MOXFF located at Pantex, ${ }^{2}$ where the base plant would be a new facility, results in estimated values for wastes generated during construction/installation of the add-on plutonium polishing facilities, as illustrated in Table 6.1.

Table 6.1. Estimated waste generated during construction/installation of plutonium polishing facilities

\begin{tabular}{|c|c|}
\hline & MOXFF \\
\hline Space factor for polishing add-on facilities & $+22 \%^{a}$ \\
\hline & Average annual numbers \\
\hline Hazardous waste & \\
\hline Liquid (paints, waste oil, etc.), $\mathrm{L}$ & 2,310 \\
\hline Solid (contaminated rags, etc.), $\mathrm{m}^{3}$ & 0.44 \\
\hline Nonhazardous (sanitary) & \\
\hline Liquid, $\mathrm{L}$ & $3,260,000$ \\
\hline Solid, $\mathrm{kg}$ & 93,400 \\
\hline Liquid, $\mathrm{L}$ & \\
\hline Solid & \\
\hline Concrete, $\mathrm{m}^{3}$ & \\
\hline Steel, MT & 37 \\
\hline Lumber, $\mathrm{m}^{3}$ & 15 \\
\hline
\end{tabular}

${ }^{a}$ Polishing add-on factor applied to base facility values taken from Table 7.1 of Response to the Surplus Plutonium Disposition Environmental Impact Statement Data Call for a Mixed-Oxide Fuel Fabrication Facility Located at the Pantex Plant, LA-UR-97-2067, March 2, 1998. (Ref. 2) 


\subsection{WASTES GENERATED FROM OPERATION}

Operations in the plutonium polishing add-on facilities will be similar to those in the base facility (the MOXFF) insofar as they are all glove-box-contained operations in which cabinet wastes (cans, wipes, used equipment, etc.), leaded gloves, and HEPA filters are generated. The volume of these wastes will be proportional to the added glove box space-estimated to be $22 \%$ of the MOXFF base facility (Table 6.2). In addition, analytical laboratory wastes, sanitary wastes, and general building maintenance wastes are similar. The wastes generated that will be significantly different in the plutonium polishing facilities will be the solidified impurities (TRU) $-\sim 0.3 \mathrm{~m}^{3}$ and the spent resin (LLW) - $\sim 0.2 \mathrm{~m}^{3}$; both of these are relatively small in volume.

\subsection{AIR EMISSIONS FROM CONSTRUCTION/INSTALLATION}

Construction/installation activities for the plutonium polishing add-on facilities will be proportional to those for the base facility. Thus, the additional air emissions are proportional to the added space which, as described in Chapter 2, will be taken as $+22 \%$ for the MOXFF.

Applying this factor to the values given in the EIS Data Report for the MOXFF located at Pantex, ${ }^{2}$ where the base plant would be a new facility, results in estimated values for air emission during construction/installation of the add-on plutonium polishing facilities, as shown in Table 6.3. 
Table 6.2 Estimated waste generated from operation of the plutonium polishing activities

\begin{tabular}{|c|c|c|c|c|}
\hline Waste category & $\begin{array}{l}\text { Annual } \\
\text { volume }\end{array}$ & $\begin{array}{c}\text { Total } \\
\text { estimated } \\
\text { volume } \\
\end{array}$ & \begin{tabular}{|c|} 
Waste description (e.g., glove box \\
gloves, cleaning solvent, paper wipes)
\end{tabular} & $\begin{array}{l}\text { Anticipated treatment and/or disposal } \\
\text { method (e.g., solidification) (specify } \\
\text { on-site or off-site) }\end{array}$ \\
\hline $\begin{array}{r}\text { Transuranic } \\
\text { Liquid, L } \\
\text { Solid, } \mathrm{m}^{3} \\
\end{array}$ & $\begin{aligned} & 0 \mathrm{~L}^{\mathrm{a}} \\
&< 20 \mathrm{~m}^{3} \\
&\end{aligned}$ & $\begin{aligned} & 0 \mathrm{~L}^{\mathrm{a}} \\
&< 200 \mathrm{~m}^{3} \\
&\end{aligned}$ & $\begin{array}{l}\text { Cabinet wastes (cans, wipes, used equipment) } \\
\text { Solidified impurities, }\left(0.3 \mathrm{~m}^{3}\right) \text { HEPA filters } \\
\end{array}$ & Disposal by shipment to WIPP \\
\hline $\begin{array}{l}\text { Mixed TRU } \\
\text { Liquid, L } \\
\text { Solid, } \mathrm{m}^{3}\end{array}$ & $\begin{array}{l}0 \mathrm{~L}^{\mathrm{a}} \\
<1 \mathrm{~m}^{3}\end{array}$ & $\begin{aligned} & 0 \mathrm{~L}^{\mathrm{a}} \\
< & 10 \mathrm{~m}^{3}\end{aligned}$ & $\begin{array}{l}\text { Leaded gloves, } \\
\text { Miscellaneous mixed wastes }\end{array}$ & Disposal by shipment to WIPP \\
\hline $\begin{array}{l}\text { LLW } \\
\text { Liquid, } \mathrm{L} \\
\text { Solid, } \mathrm{m}^{3}\end{array}$ & $\begin{array}{c}0 \mathrm{~L} \\
60 \mathrm{~m}^{3}\end{array}$ & $\begin{array}{c}0 \mathrm{~L} \\
600 \mathrm{~m}^{3}\end{array}$ & $\begin{array}{l}\text { Spent resin }\left(0.2 \mathrm{~m}^{3}\right) \text {, Miscellaneous metal } \\
\text { and combustibles }\end{array}$ & Disposal by shallow land burial \\
\hline $\begin{array}{l}\text { Mixed LLW } \\
\text { Liquid, L } \\
\text { Solid, } \mathrm{m}^{3}\end{array}$ & $\begin{array}{c}0 \mathrm{~L} \\
1.0 \mathrm{~m}^{3}\end{array}$ & $\begin{array}{c}0 \mathrm{~L} \\
10 \mathrm{~m}^{3}\end{array}$ & $\begin{array}{l}\text { Occasional waste items or solidified wastes } \\
\text { from analytical lab }\end{array}$ & Off-site treatment/disposal facility \\
\hline $\begin{array}{l}\text { Hazardous } \\
\text { Liquid, L } \\
\text { Solid, } \mathrm{m}^{3}\end{array}$ & $\begin{array}{l}740 \mathrm{~L} \\
1.0 \mathrm{~m}^{3} \\
\end{array}$ & $\begin{array}{l}7400 \mathrm{~L} \\
10 \mathrm{~m}^{3}\end{array}$ & $\begin{array}{l}\text { Occasional lab wastes, oils, lubricants, } \\
\text { cleaning solvents }\end{array}$ & Off-site treatment/disposal facility \\
\hline $\begin{array}{l}\text { Nonhazardous (Sanitary) } \\
\text { Liquid, L } \\
\text { Solid, } \mathrm{m}^{3}\end{array}$ & $\begin{array}{c}1,380,000 \mathrm{~L} \\
110 \mathrm{~m}^{3}\end{array}$ & $\begin{array}{c}13,800,000 \mathrm{~L} \\
1100 \mathrm{~m}^{3}\end{array}$ & "Sanitary Water" & Off-site treatment/disposal facility \\
\hline $\begin{array}{l}\text { Nonhazardous (Other) } \\
\text { Specify by waste: } \\
\text { Liquid, L } \\
\text { Solid, } \mathrm{m}^{3}\end{array}$ & $\begin{array}{l}410 \mathrm{~L} \\
180 \mathrm{~m}^{3}\end{array}$ & $\begin{array}{l}4,100 \mathrm{~L} \\
1,800 \mathrm{~m}^{3}\end{array}$ & Storm water, solid industrial wastes, trash & Landfill \\
\hline
\end{tabular}

${ }^{a}$ These volumes are based on < $22 \%$ of the values given in the Response to the Surplus Plutonium Disposition Environmental Impact Statement Data Call for a Mixed-Oxide Fuel Fabrication Facility Located at the Pantex Plant, LA-UR-97-2067, March 2, 1998. (Ref. 2) 
Table 6.3 Air emissions from construction/installation of plutonium polishing facilities

\begin{tabular}{|l|c|}
\hline & MOXFF \\
\hline Space factor for polishing add-on facilities & $+22 \%^{a}$ \\
\hline Pollutant & Average Annual Numbers \\
\hline Carbon monoxide, MT & 0.70 \\
\hline Oxides of nitrogen $\left(\mathrm{NO}_{\mathrm{x}}\right), \mathrm{MT}$ & 1.9 \\
\hline Particulate matter (PM-10), MT & 0.14 \\
\hline Oxides of sulfur (SO $), \mathrm{MT}$ & 0.19 \\
\hline Volatile organic compounds, MT & 0.13 \\
\hline Other regulated pollutants & \\
\hline Total suspended particulates, MT & Not listed \\
\hline Hazardous air pollutants, MT & $<0.2$ \\
\hline (e.g., lead, benzene, hexane, asbestos) & \\
\hline
\end{tabular}

${ }^{a}$ Polishing add-on factor applied to base facility values taken from Table 7.2 of Response to the Surplus Plutonium Disposition Environmental Impact Statement Data Call for a Mixed-Oxide Fuel Fabrication Facility Located at the Pantex Plant, LA-UR-97-2067, March 2, 1998. (Ref. 2)

\subsection{AIR EMISSIONS DURING OPERATION}

Most of the air emissions will come from general facility operations, including heating, cooling, and ventilation systems. These types of air emissions coming from the plutonium polishing addon facilities are proportional to the added space required for the base facility, as indicated in Table 6.4 The processing will add relatively small amounts of nitrogen oxides and n-paraffin hydrocarbons as indicated in Table 6.4.

Table 6.4 Air emissions from operation of plutonium polishing processes

\begin{tabular}{|l|c|}
\hline \multicolumn{1}{|c|}{ Pollutant } & Annual emissions, MT \\
\hline Oxides of nitrogen $\left(\mathrm{NO}_{\mathrm{x}}\right)$ & +0.86 \\
\hline $\begin{array}{l}\text { Hazardous air pollutants } \\
\text { (e.g., lead, benzene, hexane, asbestos) } \\
\text { specify, as appropriate }\end{array}$ & $\begin{array}{c}0.0080 \\
\text { (n-paraffin hydrocarbon) }\end{array}$ \\
\hline
\end{tabular}




\subsection{RADIOACTIVE RELEASES DURING OPERATION}

Radioactive releases from the plutonium polishing operations to the off-gas (air) will be similar to those from the PDCF because an additional operation which generates and handles plutonium oxide powder is added. Similar HEPA filtration will be used. Thus, the value shown in Table 6.5 for the plutonium polishing activities is the same as that estimated for the PDCF. ${ }^{3}$

Table 6.5 Radioactive releases during operation of plutonium polishing facilities

\begin{tabular}{|l|l|l|l|}
\hline Stream & Radionuclide & \multicolumn{1}{|c|}{ Plutonium release } & Average release height $(\mathbf{m})$ \\
\hline Air & $2 \mu \mathrm{Ci} / \mathrm{year}^{a}$ & $1.65 \times 10^{-8} \mathrm{~g} / \mathrm{year}(2 \mu \mathrm{Ci} / \mathrm{year})$ & Base facility stack \\
\hline Water & & Not applicable & Not applicable \\
\hline
\end{tabular}

${ }^{a}$ Based on assumed weapons plutonium composition of $25 \mathrm{ppb}{ }^{236} \mathrm{Pu} ; 0.05$ wt $\%{ }^{238} \mathrm{Pu} ; 92.33$ wt $\%{ }^{239} \mathrm{Pu} ; 6.5$ wt $\%{ }^{240} \mathrm{Pu} ; 1.0$ wt $\%{ }^{241} \mathrm{Pu} ; 0.1$ wt $\%{ }^{242} \mathrm{Pu}$; and $200 \mathrm{ppm}{ }^{241} \mathrm{Am}$. 


\section{OPERATIONAL ACCIDENT ANALYSIS}

The plutonium polishing facilities are to be treated as an add-on to the MOXFF base facility. Thus, the following accident scenarios represent bounding cases that could be encountered in the add-on liquid phase operations-dissolution, impurity removal, conversion to oxide, and acid recovery operations. While accidents involving powder handling could also occur in the plutonium polishing facilities, they would be similar to those described in the environmental data reports for the base facility. In fact, for the overall facility, the potential accidents involving powder releases are the bounding accident scenarios.

\subsection{METHODOLOGY AND ASSUMPTIONS}

Excerpts from Safety Analysis Reports from ORNL, ${ }^{4}$ LANL, ${ }^{5}$ and SRS ${ }^{6}$ were used to define most of the postulated accident scenarios. Similarly to the PDCF data report, the methodology used to estimate the source term was

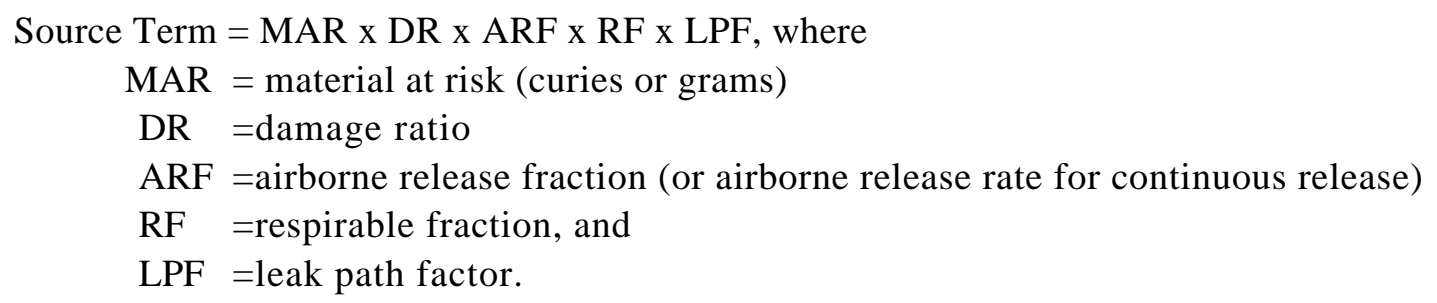

To estimate source terms using this equation, the MAR was estimated from a knowledge of the process to be employed. The DR was assumed to be 1.0. The ARF and RF were estimated according to reference material in Airborne Release Fractions/Rates and Respirable Fractions for Nonreactor Nuclear Facilities, (DOE-HDBK-3010-94). ${ }^{7}$ The LPF was based on two stages of HEPA filtration with efficiencies assumed to be 0.99 and 0.999 , giving a total LPF of $1.0 \times 10^{-5}$, even though more levels of confinement are normally utilized.

Accident scenario frequencies were estimated, in some cases by site fault tree analyses, or by engineering judgement while considering the various factors for the primary initiating events for a scenario. In general, the following criteria were used to define three accident frequency categories, as follows:

$\begin{array}{lr}\text { Anticipated Events: } & >10^{-2} \text { per year } \\ \text { Unlikely Events: } & 10^{-2} \text { to } 10^{-4} \text { per year, and } \\ \text { Extremely Unlikely Events: } & <10^{-4} \text { per year. }\end{array}$

Anticipated events are those incidents and events of moderate frequency that may occur once or more during the life of the facility. Unlikely events are those incidents or events that are not expected, but may occur during the lifetime of the facility. Extremely unlikely events are those that are not expected to occur during the lifetime of the facility. 


\subsection{LIQUID-PHASE OPERATIONAL ACCIDENTS}

Liquid-phase operations will be contained in tanks, columns, or other process equipment and, in most cases, the process equipment will be contained in glove boxes with controlled ventilation. In all cases, the glove boxes or storage tanks will be contained inside a controlled and ventilated area, or room, which is contained within the process building.

\subsubsection{Spills}

Leakage of liquids from process equipment must be considered as an "anticipated event," with an occurrence frequency of $>10^{-2}$ per year. However, with the multiple containment barriers, a release from the process room would be an "extremely unlikely event," with an occurrence frequency $<10^{-4}$ per year. Under these conditions, leakage from the process building would not be credible. If, however, the tank is not located within a glove box, there are only two containment barriers (the room and the building) and the scenario is credible, but "extremely unlikely."

Sumps designed to collect liquid leakage in a subcritical geometry will be designed for each glove box and each process room. Liquid-level and radiation detectors will be located in the sumps and will be alarmed to notify operating personnel of any accumulated leakage.

A bounding-accident scenario is for a liquid spill of concentrated aqueous plutonium solution (100 g/L plutonium) with $50 \mathrm{~L}$ of liquid accumulated before the leak is stopped. Thus, the MAR is $5000 \mathrm{~g}$. The ARF/RF values listed in Ref. 7 are $2 \times 10^{-4}$ and 0.5 . Using the LPF of $1 \times 10^{-5}$, the plutonium release from the facility would be $5 \times 10^{-6} \mathrm{~g}\left(5000 \times 2 \times 10^{-4} \times 0.5 \times 1 \times 10^{-5}\right)$.

\subsubsection{Fire}

The occurrence of a fire requires three constituents: fuel, oxygen, and heat. If any constituent is not present in the proper proportions, then a fire will not occur. If one constituent is sufficiently altered, then the fire goes out. If a fire were to occur in solvent extraction, it would probably occur outside the centrifugal contactors in the solvent extraction glove box sump. In addition, the solvent must be heated to the fire point which is $10^{\circ}$ to $70^{\circ} \mathrm{C}$ above the flash point. The fire point is defined as the lowest temperature at which a mixture of air and vapor continues to burn in an open container when ignited. Once the solvent has been heated above the fire point, a fire can occur if an ignitor is available. Examples of ignitors are adjacent fires, electrical shorts, friction, and static electricity. The event tree determined at $\mathrm{SRS}^{6}$ for process related fire initiators in solvent extraction operations resulted in an estimated probability of $6.1 \times 10^{-4} /$ year. This was a larger scale and more complex facility than proposed for processing weapons plutonium; thus, the probability in the proposed facility should be even smaller.

The scenario for ignition of liquid organic solvent assumes that the liquid organic solvent (30\% tri-butyl phosphate (TBP) in n-paraffin hydrocarbon diluent) containing the maximum plutonium concentration of $40 \mathrm{~g} / \mathrm{L}$ leaks as a spray into the glove box, builds to a flammable concentration and is contacted by an ignition source. This is an extremely low probability because the centrifugal contactors are not pressurized. The diluent, n-paraffin hydrocarbon has a relatively 
low vapor pressure similar to kerosene. Each solvent extraction contactor has a holdup volume of $\sim 0.5 \mathrm{~L}$, and the solvent flow rate is $1 \mathrm{~L} /$ minute. Leakage would occur as a liquid spray which would dissipate quickly into a nonflammable condition, unless ignited. The bounding assumption for the MAR is $1 \mathrm{~L}$ of solvent containing $40 \mathrm{~g}$ of weapons-grade (WG) plutonium. Reference 7 lists an ARF/RF bounding value of $1 \times 10^{-2}$ for quiescent burning, small surface area pools, or small solvent layer over large aqueous layer burning to self-extinguishment. The airborne source term is $0.40 \mathrm{~g}\left(40 \times 1 \times 10^{-2}\right)$. Using the LPF of $1.0 \times 10^{-5}$ and assuming that all of the airborne plutonium is swept into the exhaust system, the resulting release from the stack would be $4.0 \times 10^{-6}$ $\mathrm{g}\left(0.40 \times 1.0 \times 10^{-5}\right)$.

\subsubsection{Explosion or Uncontrolled Reaction}

Explosive gases, such as hydrogen, will not be used in the plutonium polishing operations. Uncontrolled accident scenarios involving a thermal excursion of nitrated anion exchange resin and a TBP-nitric acid or a hydroxylamine-nitric acid reaction in an evaporator are described below for the plutonium polishing operations. However, neither is as severe as the hydrogenexplosion-driven release scenarios involving multikilogram amounts of plutonium in other base facility operations. Thus, the design-basis accident scenario for explosion events will not be changed by the addition of plutonium polishing operations.

\subsubsection{Scenario for thermal excursion in an anion exchange column}

This scenario examines the potential effects of a thermal excursion within an ion exchange column. The thermal excursion is postulated to result from off-normal operations, degraded resin, or a glove box fire. It is also assumed that the column venting/pressure relief fails to vent the overpressure causing the column to violently rupture. The overpressure releases plutonium nitrate solution as an aerosol within the affected glove box which in turn is processed through the ventilation system. If the overpressure also breeches the glove box, a fraction of the aerosol will be released within the room as well.

The total mass of WG plutonium that could be contained in an ion exchange column is $1000 \mathrm{~g}$ on the resin and $246 \mathrm{~g}$ in nitrate solution. These quantities are based on the maximum intended plutonium loading of the resin and the maximum intended plutonium concentration in solution after $\mathrm{pH}$-adjustment respectively. Reference 7 lists ARF/RF values of $9 \times 10^{-3}$ for burning resin and $6 \times 10^{-3}$ for liquid behaving as a flashing spray upon depressurization.

The vinyl pyridine polymer-based resin (Reillex HPQ) used in the ion exchange columns is stable under both high temperature conditions and after extended exposure to radiation. Experiments

have demonstrated the stability of the resin under these conditions and the resin is not expected to burn upon release because of an overpressurization of the column. However, as a conservative assumption for the evaluation, $10 \%$ of the resin is assumed to burn upon release. This fraction is incorporated in the source term equation below as a DR of 0.10 . With a MAR of $1000 \mathrm{~g}$ of plutonium loaded on the resin and the listed ARF/RF of $9 \times 10^{-3}$ from Ref. 7, the airborne source term contribution from burning resin is $1000 \mathrm{~g} \mathrm{x} 0.10\left(9 \times 10^{-3}\right)=0.9 \mathrm{~g}$. 
The volume of the plutonium nitrate solution in the ion-exchange column is $2.46 \mathrm{~L}$. With a plutonium concentration of $100 \mathrm{~g} / \mathrm{L}$, this equates to a MAR of $246 \mathrm{~g}$ of plutonium. The ARF/RF is $6 \times 10^{-3}$ and the DR is 1.0 for this case because all of the solution is assumed to be acted upon by the overpressure. This is a conservative assumption because not all of the liquid may be ejected from the column because of the overpressure. The airborne source term contribution from the flashing solution is $246 \mathrm{~g} \mathrm{x} 1.0 \times\left(6 \times 10^{-3}\right)=1.5 \mathrm{~g}$.

Summing these two airborne source terms from the resin and the solution gives a total of $2.4 \mathrm{~g}$ of plutonium aerosol in the glove box.

The LPF is assumed to be the same as that described for the base facility, which is two stages of HEPA filtration with efficiencies assumed to be 0.999 and 0.99 , giving a total LPF of $1.0 \times 10^{-5}$. Assuming all of the airborne plutonium in the glove box would be swept into the off-gas system, the resulting release from the stack would be $2.4 \times 10^{-5} \mathrm{~g}\left(2.4 \mathrm{~g} \mathrm{x} 1.0 \times 10^{-5}\right)$.

With regard to probability, process controls are used to ensure that nitrated anion exchange resins are maintained in a wet condition, that the maximum nitric acid concentration and the operating temperatures are limited to safe values, and that the time that plutonium is absorbed on the resin is minimized. With these controls in place, an engineering study at $\mathrm{ORNL}^{4}$ estimated the frequency of a thermal excursion accident as "unlikely."

\subsubsection{Nitric acid-reactant events}

Uncontrolled reactions, including explosions, of "fuel" materials with nitric acid, which is a strong oxidizer, are possible. Two examples of occurrences are the TBP—nitric acid ("red oil") explosions at Department of Energy (DOE) facilities and the more recent hydroxylamine nitratenitric acid explosion at the Hanford Z-Plant. Because of these known possibilities, several engineering safeguards and administrative procedures are used to reduce the probability (frequency) of such an occurrence to an acceptable level. For example, in the proposed weapons plutonium processing facilities described in this data report, the aqueous streams leaving the solvent extraction contactors are to be treated by washing with n-paraffin hydrocarbon diluent to remove entrained and dissolved TBP, before sending the aqueous solution to an evaporator. Also, excess hydroxylamine nitrate in the aqueous oxalate filtrate stream is to be decomposed at low temperature by sparging with nitric oxide gas, before evaporation of the filtrate solution. With these precautionary measures in place, the probability of an uncontrolled reaction occurrence can be reduced to "extremely unlikely."

Plutonium release consequences can be estimated for an uncontrolled nitric acid-hydroxylamine reaction in the oxalate filtrate evaporation reboiler. The plutonium concentration is expected to be $0.11 \mathrm{~g} / \mathrm{L}$ in the evaporator concentrate solution, and the solution inventory in the evaporator will be about $25 \mathrm{~L}$. Thus, the plutonium inventory (MAR) will be $2.75 \mathrm{~g}$. The bounding ARF/RF values given by Ref. 7 for high pressure releases of aqueous solutions are $2 \times 10^{-3} / 1.0$. Thus the plutonium release from the event would be $5.5 \times 10^{-3} \mathrm{~g}$. Assuming that the facility off-gas filtration system remains intact, the LPF is $1 \times 10^{-5}$ and the plutonium release from the facility stack would be $5.5 \times 10^{-8} \mathrm{~g}$. 


\subsubsection{Criticality}

In comparison to the criticality accident scenario described in Sect. 7 of the PDCF data report for plutonium in metal form, criticality accident characteristics and shutdown mechanisms for liquid solution accidents are different. These differences are described in an Oak Ridge Y-12 Plant publication (Study Guide for Nuclear Criticality Safety Requalification Training for Supervisors, Y-TC-0020, July $1994^{8}$ ) and are listed in the following.

\section{Nuclear criticality accident characteristics}

\section{Metal accident}

- usually a single, sharp pulse

- $\quad$ short time

- unmoderated (mostly "fast" neutron fissions)

- generally high fission yield than solution accident

\section{Solution accident}

- usually a broader pulse that may be a single burst or repetitive bursts

- longer time

- moderated (mostly "slow" neutron fission)

- possibly lower fission yield than metal accident

Nuclear criticality accident shutdown mechanisms

\begin{tabular}{ll}
\hline \multicolumn{1}{c}{ Metal accident } & \multicolumn{1}{c}{ Solution accident } \\
\hline - material breaks apart & - boiling/bubbling \\
- melting & $\bullet$ evaporation \\
- vaporization & $\bullet \quad$ material splattered \\
\hline
\end{tabular}

In the LANL safety analysis report (SAR) for the TA-55 facility, ${ }^{5}$ the maximum expected criticality yield for a liquid solution event was selected as $5 \times 10^{17}$ fissions. Two source terms were developed at LANL and evaluated for the evaluation basis criticality accident: an unmitigated source term that was evaluated in terms of its associated off-site consequences and was used to identify the need for safety-class SSCs; and a realistic source term that reflects existing facility features (i.e., ventilation and filtration). To estimate the fission products and plutonium that might be released in a postulated nuclear criticality accident, the guidance provided in Assumptions Used for Evaluating the Potential Radiological Consequences of Accidental Nuclear Criticality in a Plutonium Processing and Fuel Fabrication Plant, Nuclear Regulatory Commission (NRC) Regulatory Guide 3.35, was followed. ${ }^{9}$ After adjusting the values of important nuclides formed and released from a criticality accident described in NRC Regulation Guide 3.35 to fit the maximum expected yield of $5 \times 10^{17}$ fissions, the total curie amounts of nuclides formed is obtained. These are listed in Table 7.1. For the unmitigated source term, it is assumed that $100 \%$ of the fission products produced are released out the stack (i.e., a LPF of 1.0). For the realistic source term, the LPF of $1.0 \times 10^{-5}$ was used. 
For the accident scenario under consideration, approximately $4.2 \mathrm{~kg}$ of plutonium as plutonium nitrate is considered to be the MAR. NUREG 1320 and NRC Regulatory Guide 3.35 recommend a value of $0.05 \%$ of the salt content of the solution evaporated as a possible aerosol for a criticality. ${ }^{9}$ The NRC Regulatory Guide ${ }^{9}$ releases are based on approximately $25 \%$ of the initial solution being evaporated. Therefore, the unmitigated consequences for the single pulse criticality are based on an aerosol containing $0.53 \mathrm{~g}$ of plutonium being released from the stack $(4200 \mathrm{~g} \mathrm{x}$ $0.05 \% \times 25 \%)$. A fault tree analysis from a criticality safety study for TA-55 was used at LANL to estimate the probability (frequency) of the liquid solution accident scenarios. Important mitigative and preventive features to the criticality event include administrative procedures to record and limit the amount of fissile material in each operation; training of operators in strict adherence to the mass limits and conduct of process operations; criticality-safe geometry of process vessels; and the multiple stages of HEPA filters through which the ventilation system directs all effluents. All criticality scenarios require at least two unlikely and independent events to occur before a criticality event is possible.

The probability of a "realistic" solution criticality accident is estimated to be $6 \times 10^{-7}$ per year. For the evaluation basis criticality accident, the consequences are assessed assuming that the structure remains intact but all mitigative features fail. This unmitigated event sequence has an estimated probability of occurrence on the order of $6 \times 10^{-11}$ per year.

\subsubsection{Beyond-Design Basis Earthquake (Total Collapse of Building)}

The contribution to the source term for the entire facility from addition of plutonium polishing operations can be estimated by supplementing the analysis described in Sect. 7.1.3.1 of the PDCF data report. ${ }^{3}$ Supplements for the instantaneous and resuspension source terms are listed below. The assumed plutonium inventory is $12 \mathrm{~kg}$ in "heavy metal solution" contained in the dissolution/impurity removal feed solution and $12 \mathrm{~kg}$ in "aqueous solution" contained in the impurity removal product/oxide conversion solution, for a total of $24 \mathrm{~kg}$ in the plutonium polishing facility. The instantaneous release is assumed to be free-fall liquid and the resuspension is assumed to be from a "homogeneous bed of powder buried under structural debris exposed to ambient conditions or under static conditions within a structure following an event." The resuspension factor is $4 \times 10^{-6} / \mathrm{h}$ for a 48 -h period, or $1.90 \times 10^{-4}$. 
Table 7.1. Source term for a criticality of $5 \times 10^{17}$ fissions

\begin{tabular}{|l|c|c|c|}
\hline Nuclide & Half-Life & $\begin{array}{c}\text { Unmitigated source } \\
\text { term }(\mathbf{C i})\end{array}$ & $\begin{array}{c}\text { Realistic source term } \\
\text { (Ci) }\end{array}$ \\
\hline $\mathrm{Kr}-83 \mathrm{~m}$ & $1.8 \mathrm{~h}$ & 5.5 & 5.5 \\
\hline $\mathrm{Kr}-85 \mathrm{~m}$ & $4.5 \mathrm{~h}$ & 3.55 & 3.55 \\
\hline $\mathrm{Kr}-85$ & $10.7 \mathrm{y}$ & $1.05 \times 10^{-5}$ & $1.05 \times 10^{-5}$ \\
\hline $\mathrm{Kr}-87$ & $76.3 \mathrm{~m}$ & $2.15 \times 10^{1}$ & $2.15 \times 10^{1}$ \\
\hline $\mathrm{Kr}-88$ & $2.8 \mathrm{~h}$ & $1.15 \mathrm{c} 10^{1}$ & $1.15 \mathrm{c} 10^{1}$ \\
\hline $\mathrm{Kr}-89$ & $3.2 \mathrm{~m}$ & $6.50 \times 10^{2}$ & $6.50 \times 10^{2}$ \\
\hline $\mathrm{Xe}-131 \mathrm{~m}$ & $11.9 \mathrm{~d}$ & $5.00 \times 10^{-3}$ & $5.00 \times 10^{-3}$ \\
\hline $\mathrm{Xe}-133 \mathrm{~m}$ & $2.0 \mathrm{~d}$ & $1.10 \times 10^{-1}$ & $1.10 \times 10^{-1}$ \\
\hline $\mathrm{Xe}-133$ & $5.2 \mathrm{~d}$ & 1.35 & 1.35 \\
\hline $\mathrm{Xe}-135 \mathrm{~m}$ & $15.6 \mathrm{~m}$ & $1.65 \times 10^{2}$ & $2.65 \times 10^{2}$ \\
\hline $\mathrm{Xe}-135$ & $9.1 \mathrm{~h}$ & $2.05 \times 10^{1}$ & $2.45 \times 10^{3}$ \\
\hline $\mathrm{Xe}-137$ & $3.8 \mathrm{~m}$ & $2.45 \times 10^{3}$ & $5.50 \times 10^{2}$ \\
\hline $\mathrm{Xe}-138$ & $14.2 \mathrm{~m}$ & $5.50 \times 10^{2}$ & $2.75 \times 10^{-1}$ \\
\hline $\mathrm{I}-131$ & $8.0 \mathrm{~d}$ & $5.50 \times 10^{-1}$ & $3.00 \times 10^{1}$ \\
\hline $\mathrm{I}-132$ & 2.3 & $6.00 \times 10^{1}$ & 4.00 \\
\hline $\mathrm{I}-133$ & $20.8 \mathrm{~h}$ & 8.00 & $1.08 \times 10^{2}$ \\
\hline $\mathrm{I}-134$ & $52.6 \mathrm{~m}$ & $2.15 \times 10^{2}$ & $1.13 \times 10^{1}$ \\
\hline $\mathrm{I}-135$ & $6.6 \mathrm{~h}$ & $2.25 \times 10^{1}$ & $5.3 \times 10^{-6}(\mathrm{~g})$ \\
\hline $\mathrm{WG}$ plutonium & & $5.3 \times 10^{-1}(\mathrm{~g})$ & \\
\hline & & & \\
\hline
\end{tabular}

Table 7.2. Total collapse instantaneous source term

\begin{tabular}{|l|l|c|c|c|c|c|}
\hline Process & Material & MAR (g) & DR & ARK & LPF & $\begin{array}{c}\text { Source } \\
\text { term (g) }\end{array}$ \\
\hline $\begin{array}{l}\text { Dissolution/impurity } \\
\text { removal feed }\end{array}$ & $\begin{array}{l}{ }^{239} \text { Pu nitrate Conc. } \\
\text { heavy metal solution }\end{array}$ & 12000 & 1 & $2 \times 10^{-5}$ & 1 & 0.24 \\
\hline $\begin{array}{l}\text { Impurity removal } \\
\text { product/oxide conversion }\end{array}$ & $\begin{array}{l}{ }^{239} \mathrm{Pu} \text { nitrate aqueous } \\
\text { solution }\end{array}$ & 12000 & 1 & $1 \times 10^{-4}$ & 1 & 1.20 \\
\hline
\end{tabular}

Table 7.3. Total collapse resuspension source term

\begin{tabular}{|l|l|c|c|c|c|c|}
\hline Process & Material & MAR (g) & DR & ARK & LPF & $\begin{array}{c}\text { Source } \\
\text { term (g) }\end{array}$ \\
\hline $\begin{array}{l}\text { Total plutonium } \\
\text { polishing facility }\end{array}$ & ${ }^{239}$ Pu nitrate & 24000 & 1 & $1.9 \times 10^{-4}$ & 1 & 4.56 \\
\hline
\end{tabular}


Table 7.4 Radionuclides released from postulated accident scenarios

\begin{tabular}{|c|c|c|c|c|}
\hline Postulated accident & Material-at-risk (g) & ARF/RF & Frequency & Material released \\
\hline $\begin{array}{l}\text { Spill (with release outside of } \\
\text { facility) }\end{array}$ & $5000 \mathrm{~g}$ plutonium & $2 \times 10^{-4} / 0.5$ & $\begin{array}{l}\text { Extremely unlikely } \\
\left(<10^{4} / \text { year }\right)\end{array}$ & $5 \times 10^{-6} \mathrm{~g}$ of plutonium \\
\hline Fire in glove box & $\begin{array}{l}40 \mathrm{~g} \text { plutonium in organic } \\
\text { solvent }\end{array}$ & $1 \times 10^{-2} / 1.0$ & Unlikely $\left(10^{2}\right.$ to $10^{-4} /$ year & $4.0 \times 10^{-6} \mathrm{~g}$ of plutonium \\
\hline \multicolumn{5}{|l|}{$\begin{array}{l}\text { Uncontrolled } \\
\text { Reaction/Explosion }\end{array}$} \\
\hline $\begin{array}{l}\text { Thermal excursion in } \\
\text { nitrate anion exchange } \\
\text { column }\end{array}$ & $\begin{array}{l}100 \mathrm{~g} \text { plutonium from } \\
\text { burning resin, plus } 246 \mathrm{~g} \\
\text { plutonium in nitrate solution }\end{array}$ & $\begin{array}{l}9 \times 10^{-3} \\
6 \times 10^{-3} \\
\end{array}$ & Unlikely & $2.4 \times 10^{-5} \mathrm{~g}$ of plutonium \\
\hline $\begin{array}{l}\text { Nitric acid-reactant } \\
\text { events }\end{array}$ & $\begin{array}{l}2.75 \mathrm{~g} \text { plutonium in aqueous } \\
\text { solution }\end{array}$ & $2 \times 10^{-3} / 1.0$ & Extremely unlikely & $5.5 \times 10^{-8} \mathrm{~g}$ of plutonium \\
\hline Criticality & $\begin{array}{l}4200 \mathrm{~g} \text { plutonium in aqueous } \\
\text { solutions }\end{array}$ & $1.25 \times 10^{-4 a}$ & Extremely unlikely & $\begin{array}{l}5.3 \times 10^{-6} \mathrm{~g} \text { of plutonium, } \\
\text { plus fission product gases }\end{array}$ \\
\hline $\begin{array}{l}\text { Beyond-design basis total } \\
\text { building collapse }\end{array}$ & $\begin{array}{l}12,000 \mathrm{~g} \text { plutonium in } \\
\text { aqueous solutions }\end{array}$ & $\begin{array}{l}2 \times 10^{-5} / 1.0 ; 1 \times 10^{-4} / 1.0 ; 1.9 \\
\times 10^{-4 b}\end{array}$ & Not credible & $1.44+4.56 \mathrm{~g}$ of plutonium \\
\hline
\end{tabular}

${ }^{a}$ Based on $0.05 \%$ converted to an aerosol and $25 \%$ evaporated.

${ }^{b}$ Half of the material has a ARF/RF value of $2 \times 10^{5} / 1.0$ and half has a value of $1 \times 10^{-4} / 1.0$. Resuspension is $1.90 \times 10^{-4}$. 


\section{REFERENCES}

1. Environmental Data Report for Generic Site Add-On Facility for Plutonium Polishing, ORNL/MD/LTR-139, Lockheed Martin Energy Research Corp., Oak Ridge National Laboratory, July 1998.

2. Response to the Surplus Plutonium Disposition Environmental Impact Statement Data Call for a Mixed-Oxide Fuel Fabrication Facility Located at the Pantex Plant, LA-UR-97-2067, Los Alamos National Laboratory, March 2, 1998.

3. Pit Disassembly and Conversion Facility, Environmental Impact Statement Data ReportPantex Plant, Los Alamos National Laboratory, Final Draft, September 12, 1997.

4. Basis for Interim Operation: Radiochemical Engineering Development Center Building 7920, Oak Ridge National Laboratory, BIO/7920-CTD/OD R1, October 13, 1997.

5. Chodak, LANL, personal communication to E. D. Collins, March 1998.

6. E. Shogen, Accident processing Accident Input to MOX EIS Westinghouse Safety Management Solutions, Inc., WSMS-SAE-98-00081, March 1998.

7. Airborne Release Fraction/Rates and Respirable Fractions for Nonreactor Nuclear Facilities, DOE-HDBK-3010-94.

8. Study Guide for Nuclear Criticality Safety Requalification Training for Supervisors, Lockheed Martin Energy Systems, Inc., Y-TC-0020, July 1994.

9. Nuclear Regulatory Commission (NRC) Regulatory Guide 3.35 “Assumptions Used for Evaluating the Potential Radiological Consequences of Accidental Nuclear Criticality in a Plutonium Processing and Fuel Fabrication Plant." 
ORNL/TM-13662

Dist. Category UC-523

\section{INTERNAL DISTRIBUTION}

1. B. B. Bevard

2. S. L. Byerly

3-5. E. D. Collins

6. B. S. Cowell

7. A. G. Croff

8-10. FMDP Library

11. C. W. Forsberg

12. E. C. Fox

13-14. S. R. Greene

15. R. T. Jubin
16. L. E. McNeese

17. G. E. Michaels

18. D. L. Moses

19. R. E. Norman

20. D. G. O'Conner

22. D. J. Spellman

23. K. A. Williams

24. Central Research Library

25. ORNL Laboratory Records-RC

26-27. ORNL Laboratory Records-OSTI

\section{EXTERNAL DISTRIBUTION}

28. D. Alberstein, Los Alamos National Laboratory, P.O. Box 1663, MS-K575, Los Alamos, New Mexico 87545

29. J. F. Baker, U.S. Department of Energy, MD-1, 1000 Independence Avenue SW, Washington, DC 20585

30. W. D. Bond, Consultant, 6704 Stone Mill Drive, Knoxville, TN 37919

31. J. J. Buksa, Los Alamos National Laboratory, P.O. Box 1663, MS-F628, Los Alamos, New Mexico 87545

32. D. O. Campbell, Consultant, 102 Windham Road, Oak Ridge, TN 37830

33. H. R. Canter, U.S. Department of Energy, MD-1, 1000 Independence Avenue SW, Washington, DC 20585

34. P. Chodak, Los Alamos National Laboratory, P.O. Box 1663, MS-K551, Los Alamos, New Mexico 87545

35. H. E. Clark, U.S. Department of Energy, Oak Ridge Operations, P.O. Box 2008, Oak Ridge, TN 37831-6269

36. S. F. DeMuth, Los Alamos National Laboratory, P.O. Box 1663, MS-F609, Los Alamos, New Mexico 87545

37. R. L. Geddes, Westinghouse Savannah River Corp., Bldg. 104, Room 704-F, Aiken SC 29808

38. C. Groome, SAIC, 20201 Century Blvd., Germantown, MD 20874

39. J. F. Heneage, Los Alamos National Laboratory, P.O. Box 1663, MS-K551, Los Alamos, NM 87545 
40. J. V. Johnson, U.S. Department of Energy, MD-4, 1000 Independence Avenue SW, Washington, DC 20585

41. J. M. McKibben, Westinghouse Savannah River Company, Building 773-A, Room A-264, Aiken, SC 29808

42. J. D. Nulton, U.S. Department of Energy, MD-3, 1000 Independence Avenue SW, Washington, DC 20585

43. D. Peko, U.S. Department of Energy, MD-3, 1000 Independence Avenue SW, Washington, DC 20585

44. P. T. Rhoads, U.S. Department of Energy, MD-3, 1000 Independence Avenue SW, Washington, DC 20585

45. T. F. Severynse, Westinghouse Savannah River Company, Building 704-F, Room 113, Aiken, SC 29808

46. G. B. Stevenson, U.S. Department of Energy, MD-4, 1000 Independence Avenue SW, Washington, DC 20585

47. J. H. Thompson, U.S. Department of Energy, MD-4, 1000 Independence Avenue SW, Washington, DC 20585

48. M. C. Thompson, Westinghouse Savannah River Company, Building 773-A, Room C-140, Aiken, SC 29808

49. A. K. Williams, Consultant, P.O. Box 12, Hathaway Pines, CA 95233

50. W. T. Wood, Los Alamos National Laboratory, P.O. Box 1663, MS-E500, Los Alamos, New Mexico 87545

51. S. L. Yarbro, Los Alamos National Laboratory, NMT-2, P.O. Box 1663, MS-E510, Los Alamos, New Mexico 87545

52. S. J. Zygmunt, Los Alamos National Laboratory, P.O. Box 1663, MS-E510, Los Alamos, New Mexico 87545

\section{WWW DISTRIBUTION}

The FMDP Web site, with a list of other relevant topical reports, is located at the following URL: http://www.ornl.gov/etd/FMDP/fmdpproc.htm 